\title{
FEDERAL URBAN RENEWAL LEGISLATION
}

\author{
Ashley A. Foard* and Hilbert Fefferdant
}

This article outlines the early origins, the struggle for enactment, and the development of federal urban renewal legislation. It also discusses separately two of several major issues which recurringly give rise to changes in that legislation. One concerns restrictions in the federal law which direct federal urban renewal aids toward the betterment of housing, as distinguished from the betterment of citics and of urban life in general. The other concerns the statutory formula for apportioning the cost of the program between the federal government and local governments. ${ }^{1}$

Perhaps no one who reads this symposium would expect a major federal program. such as urban renewal, even though it may be urgently needed and broadly supported, to be quickly formulated in detail adequate for enactment and swiftly enacted into law. A few might, however, underestimate the pitfalls and the time required. Some delays are inherent in the routine operations of the democratic legislative: process, but the greatest delays in obtaining the enactment of legislation are to be expected when there are many diverse and important interests involved; and this. may be true even after there is much agreement that the legislation's underlying. purpose is good. The history of the basic federal urban renewal statute-Title I of. the Housing Act of $1949^{2}$-was not exceptional in this regard. It involved very manydiverse interests and extended over a period of many years. ${ }^{3}$

\section{I}

\section{Early Origins of the Federar Law}

The major outlines of the 1949 legislation were distinctly visible in proposals.

- J.D. 1934, University of Chicago. Associate General Counsel, Housing and Home Finance Agency. Member of the District of Columbia and Illinois bars.

fLL.B. 1937, Harvard Law School. Assistant General Counsel, Housing and Home Finance Agency. Nember of the New York bar.

The views expressed are those of the writers, who in no way purport in this article to speak for the Housing and Home Finance Agency.

${ }^{2}$ Current problems concerning compensation to those displaced by urban renewal activities for loss. of projerty or for muving expenses and problems relating to the provision of housing for displaced persons are dealt with in other parts of this symposium.

: 63 Stat. $413,414,42$ U.S.C. 5 I 441 et seq. (1958).

= Because the lengthy legislative history is crowded with many bills, hearings, and reports, this article: will be burdened with many references and dates which are included largely to fill the needs of readers who may wish to consult the inadequately indexed primary sources. Howeter, it is not possible within the space available to describe the history of detailed provisions of the law. Neither would it be very helpful, cren if possible, to trace the basic provisions of the statute to the first person or persons who. may have proposed them. As is so often true when problems are widely felt, similar solutions often. occur at about the same time to many persons independently. The writers have not infrequently drafted laws to conform to legislative solutions hammered out in their presence, only to hear strangers later claim, obviously in good faith, to be the authors of the proposals. In some cases work, while unknown to the writers as draftsmen, had infuenced their principals; and in other cases, work, though done earlier, had gone unnoticed when the legislation was written. 
made as early as $194 x^{4}$ A Handiook on Urban Redevelopment for Cities in the United States, published in November 1941, by the Federal Housing Administration, dealt with the problems of urban slums and blight and with the need for municipal rehabilitation and redevelopment. It recommended a planning agency for each city and also a corporate arm of local government to be known as a "city realty corporation" with broad powers to acquire, hold, and dispose of real property for redevelop-ment, including the power to acquire sites through eminent domain. This proposal contemplated the long-term leasing of tracts, before or after clearance of buildings, to privately-financed redevelopment corporations for construction in accordance with approved plans conforming to the master plan of the city. The possible need for federal financial aid to the community was suggested.

In December of the same year, 1941, a proposal conforming in more details to the federal urban redevelopment program as later authorized was made in an article, Urban Redevelopment and Housing, by Guy Greer and Alvin H. Hansen. ${ }^{5}$ It opens with the following statement:

With few exceptions, our American cities and towns have drifted into a situation, both physically and financially, that is becoming intolerable. Their plight, moreover, is getting progressively worse.

The authors listed as the two chief obstacles in the way of replanning by the cities and of rebuilding by private enterprise: first, the lack of adequate powers in local governments to control the use of land; and secondly, the frozen status of high land costs in slum and blighted areas. The following are features of their proposal for removing these two obstacles:

I. Federal loans or subsidies to communities for the elimination of slums and blighted areas, and technical aid to planning agencies of the communities.

2. Comprehensive state enabling legislation granting necessary powers to the city or a "special unit" of local government, especially to authorize the acquisition of land through eminent domain where necessary.

3. Requirements that the proposed redevelopment plan (i) be in accordance with

- Proposals for eliminating slums and blight were, of course, made much earlier. See, for example, the carly suggestions made or referred to in the following publications: 3 THE Presidenr's [Hoovex] CONference on Home Building and Home Ownership ch. I, app. VII (I932); Symposium, Low Cost Housing and Slum Clearance, I Law \& Contemp. ProB. 135-256 (1934); II JaMes Ford, SLUMs AND Housing chs. 27, 30, 35 (1956); Engle, The British Housing Program, rgo Annars 191 (1937); Keppler, Housing in the Netherlands, id. at 205; MABEl L. Walker, Urban Blicht aNd SluMs chs. 25, 28,29 (12 Harvard City Planning Studies 1938). The earlier proposals are not reviewed here because they did not receive the direct attention of the congressional committees which considered urban re- development legislation, or because they selate to experience in other countries, or are not directed to federally-aided programs, or are not stated in much detail. Also, many earlier and detailed proposals for federal aid are not within the scope of this article because they approach the problem of eliminating slums and blight primarily through federal aid for low-rent housing construction, thereby conforming to the pattern of the United States Housing Act of 1937, rather than of the 1949 legislation. For example, in National Resources Committee, Our Cities-Their Role in the National Economix (1937), contrast the very general reference to cooperation by the federal government under the heading "Abolition of the Slum" (id. at 75) with the specific recommendations for federal action unider the headings "Housing" (id. at 76) and "Six" (id. at xi).

s Published as 2 pamphlet by the National Planning Association. 
a master plan for the community, and (ii) indicate the future use of each portion of the acquired area, whether to be used for public or private purposes.

4. Acquisition by local governments of land in slum and blighted areas with funds advanced from the federal government, as a step preliminary to demolition and redevelopment.

5. Use of land for redevelopment to be independent of acquisition cost to the community, and recognition that acquisition cost of slum and blighted areas would normally exceed the direct dollar return to the community for use of the land.

6. Repayment of federal advances, to the extent possible, from proceeds from use of the land, but recognition of need for federal loss of funds.

7. Provision of public works in relation to the undertaking.

8. Demolition and rebuilding or rehabilitation to proceed as rapidly as feasible.

9. The quid pro quo of federal financial aid should be the initiation by the urban community of a long-range program of replanning and rebuilding.

With one important modification, the first eight of these features are to be found in the federally-aided program as contemplated by the $1949 \mathrm{Act}$, and the ninth is strikingly similar to the requirement enacted in 1954 that the locality shall, in return for the federal aid, adopt a long-range "workable program" for dealing with its overall problem of slums and blight.

The major difference between the I94I proposal and the 1949 Act relates to the type of federal subsidy. The Greer-Hansen proposal contemplated a subsidy, indefinite in amount, which would be made available over a long period of time. 'This form of subsidy appears to be geared to the expectation (which Greer and Hansen shared with the authors of the I94I FHA Handbook) that the land would normally be made available to private redevelopers under long-term leases, which would make the net loss on each project depend upon rentals paid over a long period of years. The 1949 Act, on the other hand, provided for a lump sum federal capital grant which would defray two-thirds of the net loss or "net project cost" as that

- Thus, it was suggested that federal advances for land aequisition might be repaid, with some interest, but only to the extent that this could be done by paying during a period of 50 years or so, something like two-thirds of the proceeds received by the municipality from leasing the land to sedevelopers. See also three other suggestions described in Hansen, Three Plans for Financing Urban Redevelopment, appearing in Hearings Bejore the Subcommittee on Housing and Urban Redevelopment of the Senate Special Committee on Post-War Economic Policy and Planning, 79th Cong. ist Sess. pt. 9, at 1622 (2945) [hereinafter cited as Taft Subcommittee Hearings]. One plan called for federal loans amortized over 100 years and bearing $1 \%$ interest, the federal subsidy consisting of the low interest sate. The city's general credit would be pledged to the repayment. $A$ second plan called for full federal guaranties of tax-exempt revenue bonds sold by the city to private investors. Revenues would consist of income from leased project land, and to the extent that the revenues were inadequate for retiring the bonds, the difference would be contributed, two-thirds by the federal government and onethird by the local government. The third plan would simply obligate the city to repay federal advances, with $1 \%$ interest, utilizing revenues from leasing project land, the general credit of the city not being pledged. The federal "subsidy" would consist of the low interest rate and the high risk of loss

Similar proposals for long-term loans (99 years) bearing very low interest rates, or even no interest, or for federal guarantecs, were made by National Housing Administrator John B. Blandford, fr., during these Hearings. Tajz Subcommittee Hearings, pt. 4, at 1052, pt. 6, at 1305. 
highly technical term is defined in the statute. Quite clearly, the act contemplates that the land would generally be sold to redevelopers in fee." When this is done, the major actual receipts are known, and it is much easier, without excessive artificiality, to calculate the federal grant as a percentage of the "net project cost." Thus, the expectation that project land would generally be sold in fee tends to reinforce the use of a "capital grant" type of federal subsidy in preference to other forms of subsidy, payable over long terms.

On April 2, 1943, Senator Thomas of Utah introduced S. 953, Seventy-cighth Congress, which closely paralleled the Greer-Hansen proposal. ${ }^{8}$ The bill would have provided for federal advances to municipalities for acquiring land to be redeveloped pursuant to local plans which had been federally approved. The advances were to be repayable, with two per cent annual interest, from rentals received by the municipality from leasing to private redevelopers project land not retained for public improvements. A later draft of the bill substituted a one per cent interest rate. ${ }^{9}$ No federal grant was proposed, the federal "subsidy" consisting of the low interest rate and the risk of loss which would result from the indefinite period for repayment and from not pledging the general credit of the city to repayment. Also, federal advances which the bill would have authorized for preparing a master city plan and for planning specific redevelopment projects would apparently have been repayable only if a loan were later made for land acquisition. Senator Wagner of New York, on June 4, 1943, introduced, at the request of the Urban Land Institute, S. 1163, Seventy-eighth Congress, which would have provided for ninety-nine year federal loans to municipalities for land acquisition. The loans would have been repayable only from the proceeds of the lease or sale of the project land, with interest to be determined by the National Housing Agency. ${ }^{10}$ Federal grants were to be limited to the locality's planning expenses.

The Thomas bill, while technically pending before the Senate Committee on Education and Labor, actually received instead the attention of the Subcommittee on Housing and Urban Redevelopment of the Senate Special Committee on Post-War Economic Policy and Planning. ${ }^{11}$ Under the very active chairmanship of Senator

'The 1949 Act also makes provision for cases where all or some of the land will be leased. \$ 302 (a) provides for "definitive" (long-term) federal loans which become necessary when the lessing of project land by the city eliminates or reduces sales proceeds available for immediate repayment of "temporary" federal loans. 73 Stat. 67142 U.S.C. \$ 1452 (a) (Supp. I959). S Iro(f) provides for imputing a value to land which is leased, this value being treated, for purposes of calculating the federal capital grant, as though it were sales proceeds. 73 Stat. 675, 42 U.S.C. 5 r460(f) (Supp. 1959).

- Professor Hansen participated in the drafting, done latgely by Alfred Bettman of Cincinnati, then Chairman of the Legislative Committce of the American Institute of Planners and also of the American Bar Association Committce on PJanning Law and Legislation.

- Draft dated Dec. 10, 1943, printed for Committee use and reprinted in Taft Sulcommittee Hearings pt. 9 , at 1625 .

${ }^{20}$ Predecessor of the present Housing and Home Finance Agency.

11 This was so because clearly any new federal aid program involving the tearing down of many structures would have to await the winning of World War II. Meanwhile, many thought it important to formulate such a program in advance of the war's end so that it would be available to help take up an expected slack in economic activity while industry converted from war to peace production. In introducing his bill, Senator Thomas stated: "It is of the highest importance that, in the reconversion from 
Taft, the Subcommittee conducted extensive and unusually searching hearings and studies between mid-1944 and mid-1945 on a very broad range of housing and urban development problems. Its report on Postwar Housing, dated August I, 1945. and printed for the use of the full Committee, recommended: ${ }^{12}$

The establishment, on a provisional basis, of a new form of assistance to cities in ridding themselves of unhealthful housing conditions and of restoring blighted areas to productive use by private enterprise.

The Subcommittee recommended that the National Housing Agency be authorized to undertake a program of loans and annual contributions to assist municipalities in acquiring and clearing slum or blighted areas and disposing of them through sale or lease for public or private purposes. Redevelopment would be in accordance with a plan for the specific project area and consistent with "a general guiding plan, prepared by an official local planning agency, for the clearance of all slums in the city." The federal annual contributions would be made for a period not exceeding forty-five years and would have the purpose "of covering the financial charges on the estimated or actual amount (whichever is the lesser) of the difference between (a) the total acquisition and demolition costs and (b) the recovery through sale or lease." The federal contributions would not exceed a fixed percentage of the financing costs involved. The municipality would be required to contribute an amount at least equal to one-half of the federal contributions, thereby in effect limiting the federal contributions to two-thirds of the net cost. The federal government would "retain the power of election to substitute a capital payment in lieu of its outstanding annual contributions commitment at any time." Federal loans for site acquisition and demolition would be authorized with maximum maturities of twenty years and at an interest rate not exceeding the "going rate" paid by the federal government on its own obligations.

The proposed federal aid formula parallels the program of loans and annual contributions for low-rent public housing authorized in the United States Housing Act of 1937. 13 Both included federal loans to the locality (at interest rates based on a "going rate" paid by the federal treasury) to cover capital outlays; federal annual contributions over long periods of time to help defray a major portion of net losses;

a wartime to a peacetime economy and the absorption of labor and resources which will be released by the termination of the war, the public expenditures which will be made shall be placed in projects which are both socially useful and economically sound." Senator Thomas in no way implied that the proposed slum-clearance program was a temporary one for the postwar period, and Senator Wagner, in introducing his bill, denied that it was a "postwar" or "public-works" or "relief" or "pump-priming" bill. He emphasized that it was instead a program of federal aid for land development and redevelopment by private enterprise, and that the problem should be faced before the war is over in order for industry, finance, and state and local governments to be "ready to act when the war is over."

${ }^{12}$ See p. 23, para. (g), and pp. 17-19. The recommendation that the program be established "on a provisional basis" is explained in the report by the need for experimentation resulting from lack of information as to the size of the task, the extent of the losses to be incurred from acquiring, clearing, and disposing of land, and the amount and nature of the aid which should be provided by the federal government.

12 so Stat. 888, 42 U.S.C. 5 140 I $^{\prime \prime}\left(195^{8}\right)$. 
and local contributions to help defray a lesser portion of the net losses. Both programs also contemplated that there would be a definite upper limit on the federal contributions but that the assured federal contributions would be sufficient to make it possible to turn to the private market for a major share of the financing. Both also made provision for an alternate type of federal subsidy in the form of a lump-sum capital grant. ${ }^{14}$ The similarities between the Taft Subcommittee's proposal and the 1937 Act are to a considerable extent traceable to experience under the 1937 Act. This is especially true of the proposal to make federal contributions over a long period of years. More important, however, are the basic underlying forces which shaped both the act and the proposal. The Subcommittee report stated that "an essential feature of any plan of Federal assistance should be provision for limiting the extent of the loss to be borne by the Federal Government and for sharing ... costs by the municipality:" The report also stated that the Subcommittee did not find in the testimony any proposals that fully conformed to these principles. Senator Taft, during the course of the hearings, had previously revealed by his questions and comments that he would oppose an indefinite subsidy such as that involved in a very low interest rate and that he would seek a federal assistance formula that involved some definite contribution from the local community or a state. ${ }^{15}$

In emphasizing the many similarities between the Taft Subcommittee's proposal and the United States Housing Act of 1937 , it is important not to lose sight of the basic difference between the two. Whereas the 1937 Act was intended to help clear slums ${ }^{26}$ through federal loans and annual contributions for the provision of

\footnotetext{
16 In fact, this authority was not used under the 1937 Act, whereas it was later adopted as the sole form of basic subsidy under the 1949 Act.

${ }^{16}$ Taft Subcommittee Hearings pt. 9, at 1612, 1613.

${ }^{10}$ The title of the I937 Act was "An Act to provide financial assistance to the States and political subdivisions thercof for the elimination of unsafe and insanitary housing conditions, for the cradication of slums, for the provision of decent, safe and sanitary dwellings for families of low income, and for the reduction of unemployment and the stimulation of business activity, to create a United States Housing Authority, and for other purposes." (Emphasis added.) The Act itself sequired the climination by demolition, effective closing, or compulsory improvement of unsafe or insanitary dwellings in the locality substantially equal in number to the dwellings provided with the federal aid. Under carlier authority, the federal government itself constructed low-rent housing projects through the Housing Division of the Public Works Administration. These were known as low-cost housing and "slum clear. ance" projects. See authority in $\$ 202$ (d) of the National Industrial Recovery Aet, 48 Stat. 195, 201 (1933). The emphasis on slum clearance purposes in the public housing legislation was thought recessary in order to justify the taking of private property through eminent domain. The elimination of slums was considered to be more clearly 2 "public purpose" involving the public health than was the construction of low-rent housing. Some may regard it as 2 paradox that, while the slum clearance purpose was emphasized by the courts during the 1930's in cases upholding the taking of private land for public housing projects, these carly housing cases (some involving slum clearance only indirectly) were sometimes the decisive factor during the 1950's in obtaining judicial approval for the taking of land by 2 city for purposes of direct slum clearance and private redevelopment.

See also $5201(2)(2)$ of the Emergency Relief and Construction Act of 2932, 47 Stat. 709, 711, under which the Reconstruction Finance Corporation' was authorized "to make loans to corporations formed wholly for the purpose of providing housing for families of low income, or for reconstruction of slum areas, which are regulated by State or municipal law as to rents, charges, capital structure, rate of return, and areas and methods of operation, to aid in financing projects, undertaken by such corporations which are self-liquidating in character." One such loan financed a large privately-owned rental housing project (Knickerbocker Village) built on a slum-cleared site in New York City.
} 
low-rent housing, the new proposal contemplated that the federal subsidy would be addressed directly to the loss from assembling, clearing, and disposing of the land, with "the same degree of assistance" being given regardless of the type of redevelopment.

Another recommendation by the Subcommittee foreshadowed a significant provision of the 1949 Act. The Subcommittee recommended that in estimating the municipality's contribution, credit be given not only for the value of land transferred to the project and the cost of streets, public utilities, and other site facilities incident to the project, but also for expenditures on "public buildings made necessary by the project." Finally, the Subcommittee contemplated, as does the 1949 Act, that land would be disposed of through sale or lease, whereas many earlier proposals were predicated on leasing as the normal, or even sole, method of disposal. ${ }^{17}$

II

\section{The Struggle for Enactment}

The history of the specific legislation which became Title I of the Housing Act of 1949 begins in 1945 in the Seventy-ninth Congress. The bill which was enacted in 1949 was one of a long series of companion or rival bills which successively and almost continuously received the attention of the Banking and Currency Committees of the House and Senate during three Congresses. On August I, 1945, Senator Wagner of New York, for himself and for Senator Ellender of Louisiana, introduced S. 1343, Seventy-ninth Congress. Its urban redevelopment provisions very closely followed the recommendations of the Taft Subcommittee report, which was dated that same day. On November 14, S. 1592, Seventy-ninth Congress, containing similar provisions, was introduced as a substitute bill by Senator Wagner of New York, for himself and Senators Ellender and Taft. Senators Wagner and Ellender had served on the Taft Subcommittee; Senator Wagner was also Chairman of the regular Committee on Banking and Currency to which S. 1592 was referred; and Senator Taft was the second ranking minority member of that Committee.

Title VI of the bill was headed "Land Assembly for Participation by Private Enterprise in Development or Redevelopment Programs." Other titles of S. 1592 provided for the establishment of a permanent national housing agency; a housing research program; grants to localities for urban planning; substantial changes in the operations of the Federal Home Loan Bank Board and the Federal Savings and

${ }^{27}$ During the-hearings, Alfred Bettman testified that the leasing policy embodied in Senator Thomas's bill was "debatable" and "should perhaps be changed so as-to permit sales." He stated: "While there is much to be said in favor of a lease land tenure policy as promotive of the stabilizing of the plans upon which the Federal aid would be based, nevertheless the time may not have as yet arrived for the adoption of that policy." Other proponents of leasing may have been motivated not only by the tighter municipal control over land use, but also by the possibility of capturing for the municipality long-range increases in land value, thereby offsetting losses due to clearance. However, members of the Subcomittee apparently felt that neither of these considerations warranted a displacement of private ownership and control (subject to restrictions in the redevelopment.plan) over large areas of urban real property. In any event, it was felt that a federa! law should certainly not be written so. as to preclude the municipality from selling project land. Taft Subcomnittee Hearings pt. 9, at $161 x$. 
Loan Insurance Corporation; extensive changes in the mortgage insurance operations of the Federal Housing Administration, including special programs for moderate income families and for cooperative housing; a new program under which the FHA would insure the annual yield on mortgage-free private investment in rental housing projects; the disposition of federally-owned war housing; a new program of loans and grants by the Secretary of Agriculture for farm housing; and authorization over a period of years for 500,000 additional low-rent public housing units. Many of these proposals were highly controversial. During the sixteen days of committee hearings held between November 27, 1945, and January 25, 1946, especially bitter opposition was expressed by the home-building, mortgage-lending, and real cstate industries to the proposed enlargement of the low-rent public housing program. While more narrowly based, there was equally vigorous opposition to many other provisions of the bill. For example, the savings-and-loan segment of the mortgagelending industry objected strongly to the inclusion of the Federal Home Loan Bank Board and the Federal Savings and Loan Insurance Corporation as subordinate agencies in the proposed permanent National Housing Agency. Although more than a little criticism was directed at the urban redevelopment title, it was clear to observers at the hearings that this title was not generating really heated objections. Indeed, the National Association of Real Estate Boards and the United States Savings and Loan League endorsed the principle of federal aid for slum clearance and urban redevelopment, while objections expressed by the National Association of Home Builders and the Mortgage Bankers of America were stated rather mildly. ${ }^{18}$

${ }^{28}$ A representative of the National Association of Real Estate Boards (which had once itself proposed federal loans for urban redevelopment) suggested that the enactment of federal aid for slum clearance and private redevelopment would enable private enterprise to do the job that public housing was supposed to do. He also testified as follows: "The National Association of Real Estate Boards strongly favors a program for urban redevelopment. ... We would want to see legislation that would assure local control of the projects from start to finish, and Federal financial assistance made in lump sum grants on a 50-50 matching basis for land assembly purposes. ... We favor putting the Federal contribution into an outright grant, because in that way you know exactly what it will cost the United States Treasury.... The annual contribution is vicious, also, in that it insures Federal domination of the municipality." Hearings Before the Senate Committee on Banking and Currency on S. 1592, General Housing ACt of 1945, 79th Cong., Ist Sess. 454-55, 480-81 (1945-46). It is true that the Association by 1947 had reversed its position and opposed federal aid for urban redevelopment. Hearings Before the Senate Committee on Banking and Currency on S. S66 Honsing, 8oth Cong., 1st Sess. 345, 363, 368 (1947). However, the main grounds for the objection at that time seemed to be that state and local aids were sufficient for such a program and that large-scale redevelopment was not likely while housing conditions were tight. By 1949, even these objections by the Association were weakened when its representative, in opposing enactment of Title I of the Housing Act of 1949, stated that he was "not necessarily" opposed to federal money for slum clearance by local redevelopment agencies, but that he was opposed to Title I "as presently written." On the same occasion, another representative of the Association, when pressed for the grounds of his objections to Title I, referred to a provision for developing "open urban land" and stated "that is our objection to the bill." Hearings Before the Senate Committee on Banking and Currency on S. 138 , General Housing Legislation, 81st Cong., 1st Sess. 4rx, 413 (1949). By 1954, the Association had come a long way around toward its original position; expressing approval of the Title I program if major emphasis were placed on conservation and rehabilization, with clearance being focused on the very worst slum pockets that cannot be rehabilitated. Hearings Before the Senate Committee on Banking and Currency on S. 2889. Housing Act of 1954, 83d Cong., 2d Sess. 440-4I (2954).

Testimony presented on behalf of the United States Savings and Loan League included the following statements: "Our people have studied the problem of slum clearance for some years and agree that it 
The omnibus bill was reported by the Senate Banking and Currency Committee on April 8, 1946, with many amendments, but with its major proposals retained. ${ }^{10}$ Despite the widespread opposition, chiefly flowing from trade associations, but with vigorous support for the bill from many professional, municipal, religious, and labor organizations, ${ }^{20}$ the bill was passed by the Senate on April I5, 1946 with overwhelming bipartisan support. There was no record vote, but during the voice vote; observers in the gallery noted that, in a well-attended chamber, not a single senator voted against final passage.

The opposition made itself far more strongly felt in the House, where opponents of the more controversial features were able to gain the support of many representatives from rural districts. Opponents of the Wagner-Ellender-Taft bill in the House rallied around a rival bill, H.R. 6205, Seventy-ninth Congress, introduced on April 18, 1946, by Representative Wolcott of Michigan, ranking Republican member of the House Committee on Banking and Currency. His bill, unlike the Senate bill, madeno provision for a permanent over-all housing agency, additional low-rent public housing, special FHA mortgage insurance aids for moderate-income families and cooperatives, FHA yield insurance on rental housing, and farm housing aids. However, the Wolcott bill did propose a federal urban redevelopment program, perhaps in recognition of the fact that this was a far less controversial proposal than those

is an appropriate field for public action and public expenditure. We have felt that the procedure could be carried out largely by local governments and that, after the land so acquired was written down to 2 . scasonable use value, it should be used for its highest and best use, public or private. We have clearly felt that it-should not be used exclusively for public housing. We think it is appropriate for the Federal Government to furnish money to be used along with funds of States and municipalities for such land assembly in the slum areas of our cities:" Criticisms of the provisions were addressed to matters of detail. The League testified that the provisions were unnecessarily complex; that the proposed annual contributions "involve a complicated and expensive approach" and that the transaction "could better be handled by direct grants at the outset"; and that the law should make it completely clear that land could be redeveloped for other than public housing purpeses and that local public housingauthorities would not necessarily administer the program locally. Hearings Before the Senate Committee on Banking and Currency on S. 1592, General Housing Act of 1945, 79th Cong., Ist Sess. 837-38, 844-45 (1945-46).

The President of the National Association of Home Builders testified against "Federal subsidies for public housing and slum clearance" in S. 1592, but, except for reference to the funds involved, his entire discussion was directed to the public housing provisions and not to the slum clearance provisions. Id. at 599-602. Testimony which was offered against the slum clearance provisions of $\mathrm{S}$. 1592 on behalf of the Mortgage Bankers of America consisted of the following relatively mild objection: "We cannot say that these provisions are the best answer to this important problem. We belicve, however, that the expenditure of federal funds at this time is inflationary and inopportune." Id. at 404-05. (Emphasis added.)

10 Senate Comm. ox Banking and Currency, General Housing Act of 1946, S. ReP. No. 1131, 79th Cong., $2 d$ Sess. (1946). The report contains both a brief summary and a detailed section-by-section analysis of the bill as reported, (The bill was debated in the Senate on April II and 15, 1946.)

${ }^{20}$ Organizations supporting the bill included the American Association of Social Workers, American Association of University Womeh, American Federation of Labor, American Public Health Association, American Veterans of World Wăr II (AMVETS), Congress of Industrial Organizations, Federal Council of Churches of Christ in-America, National Associntion of Housing Officials, National Board of the Young Women's Christian Association, National Catholic Welfare Council, National Conference of Catholic Charities, National Council of Jewish Women, National Institute: of Municipal Law Officers, United States Conference of Mayors, and Veterans of Foreigh Wars: of the United States. 
excluded from the bill.21 Although the proposal differed greatly from that in the Senate bill, it gave support to the principle that substantial federal aid was warranted for this purpose. Thus, the Wolcott bill would have authorized the Reconstrucion Finance Corporation to make $\$$ i billion of federal loan funds and $\$ 1$ billion of federal capital grants available to localities for slum clearance projects. The major difference in the federal formula under the two bills was that federal grants under the Wolcott bill would have been limited to one-half, rather than two-thirds, of the net project cost. ${ }^{22}$

Hearings on general housing legislation were scheduled in the House Committee on Banking and Currency on June 28 and 29, and on July 1, 3, and 5, 1946. On each occasion, the Committee adjourned on a point of order raised by opponents of the Wagner-Ellender-Taft bill on the grounds that the House was in session. The House hearings were neither completed nor published, and the Seventy-ninth Congress adjourned on August 2, 1946, without the bill having reached the floor of the House. This was only the beginning of a long series of similar disappointments to be suffered by the sponsors of general housing legislation and of federal aid for urban redevelopment.

A successor bill, S. 866, was introduced in the Eightieth Congress on March 10, 1947, by Senator Taft, for himself and Senators Ellender and Wagner, and came to be known as the Taft-Ellender-Wagner bill. Its urban redevelopment provisions did not differ much from those in S. $15922^{23}$ S. 866 was reported by the Senate Banking and Currency Committee in April, 1947 after hearings during March and April."4

The battle lines which had formed in 1945 and 1946 around the Wagner-EllenderTaft bill shifted very little during 1947 , 1948, and the first six months of 1949, as the Taft-Ellender-Wagner bill was considered, modified, and superseded by other comprehensive housing bills. The intensive legislative battles during this entire period involved no important new positions, even though many skirmishes were fought over new terrain under new leaders utilizing new tactics. For example, the terrain was changed when a special Joint Committee on Housing was appointed in July 1947 to make a new study and investigation of housing. Its Chairman, Representative Gamble of New York, and its Vice Chairman, Senator McCarthy of Wisconsin, opposed many of the important provisions in the Wagner-Ellender-Taft bill. The Committee held very extensive hearings from September 1947 through January 1948,

\footnotetext{
"Senator Ellender recognized this fact when he inserted in the Congressional Record twelve questions and answers which were later printed as a pamphlet, Objections to the Wagner-Ellender-Tajt Bill Are Not Valid. Not one of the questions or objections was addressed to the urban redevelopment program. Sce 92 CoNc. REc. 3699 (1946).

2" Perhaps a mutive for assigning the program to the RFC was to avoid giving aid and comfort to the proponents of a permanent national housing agency.

22 A detailed comparison of the two bills appears in Part 6 of a pamphlet prepared by the Legislative Reference Service of the Library of Congress for the use of the Senate Committee on Banking and Currency, The Genfraz Housinc Bri-Arguments fon and Aganst Senate Bill 1591, 80th Cong., ist Sess. (Comm. Print 1947).

"Senate Comm. on Banking and Currency, National Housing Commission Aat, S. REP. No. 140, 8oth Cong., ist Sess. (1947).
} 
while proponents of comprehensive housing legislation charged that this was a delaying tactic by the Chairman and Vice Chairman. However, a majority of the Committe did in fact favor the Taft-Ellender-Wagner bill, and its Final Majority Report of March 15, 1948, reflected that fact. ${ }^{25}$ Here again, urban redevelopment proposals were not the subject of major differences of opinion concerning basic principles. ${ }^{26}$

Amendments to conform S. 866 to the recommendations of the Joint Committec were introduced by Senator Flanders of Vermont, simultaneously with the publication of the final report of the Joint Committee on March 15. Hearings on these amendments were held on March $3^{1}$ and April I by the Senate Banking and Currency Committee, and the amendments were reported on April 8.7 They included a number of significant changes in the urban redevelopment provisions. ${ }^{28}$ The most note:worthy from a long-range viewpoint was the change from a system of federal annual contributions for slum clearance to a system of capital grants. This change had been recommended during the hearings in the Seventy-ninth Congress by the National Association of Real Estate Boards and the United States Savings and Loan League. ${ }^{28}$ During the Eightieth Congress, it was concurred in by the Housing Administrator, who stated: "This seems to be a desirable improvement, since the amount of the subsidy necessary would become fixed when the land in a project area had been assembled, cleared, and sold or leased for redevelopment, and there would not appear to be any possibility of savings to the Government through the use of a system of annual contributions. Further, of course, Senator Flanders' amendments . . . would reduce very substantially the period when substantial Federal supervision of project accounts and revenues would be required." ${ }^{29}$ Another change was the new requirement that the Housing Administrator, in extending financial aid under the urban redevelopment title, "give consideration" to the extent to which the locality has undertaken a program to encourage housing cost reductions through the adoption and improvement of building and other local codes. ${ }^{30}$

The Senate debated the bill at great length and passed it by voice vote on April

${ }^{28}$ Joint Comm. on Housing, Final Majority Report, Housing Study and Investigation, H.R. REP. No. 1564 , 8oth Cong., $2 \mathrm{~d}$ Sess. (1948).

2" Compare Joint Comm. on Housing, Housing Study and Investigation, S. REp. No. 1org, 8oth Cong., 2d Sess. 6-7, 18, 20 (1948), with Joint Comm. on Housing, Final Majority Report, H.R. REP. No. 1564, 8oth Cong., 2d Sess., at 24-25 (r948) (individual views of Senator McCarthy).

${ }^{2}$ Senate Comm. on Banking and Currency, Housing Act, S. REp. No. 140, 8oth Cong., 2d Sess. pt. $2(1948)$.

${ }^{98}$ See Senate Comm. on Banking and Currency, Housing Act, S. ReP. No. 140, 80th Cong,, 1st Sess. pt. 2 (1948), for a section-by-section analysis of $S .866$ as reported in 1948 ; a comparison with the legislative recommendations of the Joint Committee on Housing; and a comparison with the bill as previously seported in 1947. See also Hearings Before the Senate Committee on Banking and Currency on Perfecting Amendments to S. 866, 8oth Cong., 2d Sess. 179-81 (1948), for the Housing Administrator's analysis of the cinanges in the urban redevelopment provisions.

insee Hearings, supra note 18.

"Hearings Before the Senate Committee on Banking and Currency on Perfecting Amendments so S. 866, 8oth Cong., $2 \mathrm{~d}$ Sess. 180 (1948).

so This was a forerunner of the so-called "workable program" requirement of the 1954 legislation referred to below. 
22, 1948, again with overwhelming bipartisan support. ${ }^{31}$ It nevertheless died in the Eightieth Congress after extensive hearings by the House Banking and Currency Committee between May 3 and June 8; the collection meanwhile of about 120 signatures on a petition by members of the House to discharge that Committce of further consideration of the bill so that it could be brought to an early vote on the floor; the introduction by Chairman Wolcott on June 8 of H.R. 6841, a substitute bill which did not contain public housing, slum clearance, and farm housing provisions; a fourteen-to-thirteen vote within the Committee on June ro to restore the omitted provisions in the form in which they appeared in the Taft-Ellender-Wagner bill; the introduction on June in by Chairman Wolcott, at the request of the Committee, of H.R. 6888, a clean bill, containing those provisions, which was reported three days later; 32 the tabling of the bill by the House Rules Committee on June 16 ; the introduction, reporting, ${ }^{33}$ and passage by the House $^{34}$ on June 16,17 , and 18 , respectively, of Chairman Wolcott's new bill, H.R. 6959, which omitted these provisions; the adjournment of the Congress for the 1948 national political conventions shortly after Senator Ellender, with the support of Senator Tobey, objected on June 19 to a unanimous consent request for the consideration of the House-passed bill; a special congressional session which started July 26, and which was called by the President primarily for the consideration of the Taft-Ellender-Wagner bill and of legislation "to check inflation"; ${ }^{35}$ the reporting of H.R. 6959 by the Senate, amended so that it was in substantially the same form as the Taft-Ellender-Wagner bill; ${ }^{36}$ the reluctant passage of that bill by the Senate after a floor amendment had removed the public housing, slum clearance and farm housing provisions; ${ }^{37}$ and the reluctant approval by the President of the Housing Act of 1948 without these major provisions. ${ }^{38}$

${ }^{31}$ Along with Senators Taft and Ellender, active supporters of the bill included Senator Tobey of New Hampshire, Chairman of the Banking and Currency Committee during the Republican Eightieth Congress and a member of the Joint Committee on Housing; Senator Flanders of Vermont, Republican member of both Committees and sponsor of the 1948 amendments to the bill; Senator Maybank of South Carolina, member of the Banking and Currene: Committee during the Eighticth Congress and its Chairman in the following Democratic Congress; and Senator Sparkman of Alabama, a member of both Committes and Chairman of the Housing and Rents Subcommittee of the Banking and Currency Committce during the Eighty-first Congress. The bill was debated in. the Senate on April $14,15,20,2 r$, and 22,1948 .

${ }^{32}$ House Comm. on Banking and Currency, Housing Act of 1948, H.R. Rep. No. 2340, 8oth Cong., 2d Sess. $(1948)$.

${ }^{33}$ House Comm. on Banking and Currency, Housing Act of 1948, H.R. Rep. No. 2389, 80th Cong., 2d Sess. (1948).

34 Under suspension of the rules, with no amendments allowed.

ss The President's Proclamation No. 2796, July 15, 1948, 13 FED. Rec. 4057 (1948), and Address by the President before a Joint Session of the Senate and the House of Representatives, Urgent Needs of the American People, H.R. Doc. No. 734, 80th Cong., zd Sess. (1948).

${ }^{30}$ Sen. Comm. on Banking and Currency, National Hottsing Act, S. Rep. No. 1773, 8oth Cong., 2d Sess. (1948).

${ }_{87}$ The Senate debate on August 5 and 6,1948 , made it abundantly clear that the Senate had reluctantly omitted these provisions only because there was insufficient time, prior to the 1948 presidential elections, to overcome the parliamentary hurdles which a minority of the membership of the House of Representatives would certainly place in the way of the broader legislation.

${ }^{88}$ Pub. L. No. 901, 80th Cong., 2d Sess. (Aug. 10, 1948), and accompanying statement by the President. 
The considerations ${ }^{39}$ which led to the omission in mid-1948 of urban redevelopment provisions from House-originated legislation were different from those which led to the omission of public housing and farm housing provisions. The public housing provisions continued to be the target of uncompromising attack, and the farm housing provisions were often characterized as wrong in principle. The urban redevelopment provisions, however, continued to escape direct attack from most of the opponents of the Taft-Ellender-Wagner bill, although latent or disguised general opposition was evident in some of the objections to matters of detail and in the fact that the provisions were omitted entirely when an unusually good opportunity to do so presented itself. The opportunity in mid-1948 for jettisoning the urban redevelopment proposal consisted of the pressure to enact, prior to the 1948 presidential elections, noncontroversial provisions for the encouragement of private housing coinstruction during a period of severe housing shortage. This shortage had led to the inclusion in the Taft-Ellender-Wagner bill, as reported to the Senate in April 1948, of provisions postponing the purchase of any urban-redevelopment-project land until July $\mathrm{I}, 1949$, and also postponing the demolition of any residential structures on such land until July I, 1950. In the light of these provisions, members of Congress moitvated by some degree of opposition to the program were able to contend thät no great harm would result from delaying enactment of the provisions until early in 1949, while substantial harm could result from the failure to enact a "half-loaf" measure. Some proponents of the urban redevelopment provisions countered that enactment was necessary in 1948 in order for land acquisition to be possible by july 1, 1949; but other proponents, recognizing that the housing shortage was not (as contemplated by the postponement provisions in their bill) likely to disappear by the summer of 1950 , were willing to overlook the mote in the eye of the opposition in view of the beam in their own.

The Eighty-first Congress convened on January 3, 1949, and two days later witnessed an apparent breach in the Senate's record of bipartisan cooperation in the field of housing when Senator Ellender, for himself, Senator Wagner, and six other Democratic Senators introduced S. 138 ; a comprehensive housing bill which consisted substantially of the unenacted parts of the Taft-Ellender-Wagner bill. ${ }^{40}$ A roughily

"Evidence of these considerations may be found both in the Senate debate of August 5 and 6 ; 1948 and in 2 report (Special Subeomm. of the Senate Comm. on Banking and Currency, Housing Act of 1948 , S. Doc. No. 202, 8oth Cong., 2d Sess. (1948)) which was made on August 7 to the Seriate Committee on Banking and Currency by three of its members who were designated by the Chairman to confer informally with members of the House of Representatives concerning housing legislation which could be enacted during the special session of Congress.

it A section-by-section summary of S. 138, 81st Cong., 1st Sess. (1949), and 2 list of the major differences between it and S. 866, as passed by the Senate in the Eightieth Congress, may be found in 95 Conc. Rec. 48-55 (1949). Among these differences were a proposed reduction in the maximum maturity of the federal urban redevelopment loans from 45 to 40 years; $i$ niew provision for federal loans for surveys and plans in preparation of urban redevelopment projects; and a new provision under which the President could, within preseribed limits, accelerate the availability of the $\$ 500$ million urbai redevelopment capital grant authorization which would otherwise become available in five equal annual installments. 
similar ${ }^{41}$ bill, S. 709, was introduced on January 27 by Republican Senator Baldwin of Connecticut for himself, Senator Taft, and fourteen other Republican Senators, thereby making up in numbers what they had lost in time, and revealing the continued presence of bipartisan support, though not cooperation. After the Senate Banking and Currency Committee had held hearings on these and other housing bills during most of February, the Committee was prepared to report out a compromise bill.2 Accordingly, in a symmetrical flourish of resumed cooperation, S. 1070, Eighty-first Congress, was introduced on February 25 under the joint sponsorship of elèven Democratic and eleven Republican Senators, including Senators Ellender, Wagner and Taft, and was reported to the Senate that same day. ${ }^{43}$ The bill was passed by the Senate on April 2I by a roll call vote of fifty-seven to thirteen. The opposition was led by Senators Bricker of Ohio and Cain of Washington, both of whom spoke chiefly against the public housing provisions." Senator Bricker apparently expressed the prevailing views of opponents in both the Senate and the House when he stated: "I am in favor of the slum elimination section. I am opposed to the public housing section. I favor the research section, and I am opposed to the farm housing section."

In the meantime, Representative Spence of Kentucky, Chairman of the House Committee on Banking and Currency, had on April 4, 1949, introduced a comprehensive housing bill, H.R. 4009 , Eighty-first Congress. The Committee held hearings during April and the early part of May and then, during three days of executive sessions, adopted many amendments designed to reduce the number of differences between the House bill and the Senate-passed bill. On May 16, H.R. 4009 was reported by a vote of fourteen to seven. ${ }^{40}$

${ }^{42}$ The most talked about difference between the Democratic and Republiean bills was in the number of low-rent public housing units authorized-r,050,000 in the former and 600,000 in the latter. In the urban redevelopment provisions, the differences were minor, with the Democratic bill providing for 40-year maximum federal loans as against 45 years in the. Republican bill and with other differences relating to merely temporary provisions governing the dates when land purchases and demolition' could begin.

the compromise consisted in large part of an 810,000 unit public bousing authorization, as against either $1,050,000$ or 600,000 .

"Senate Comm. on Banking and Currency, Housing Act of 1949, S. REP. No. 84, 7rst Cong., Ist Sess. pt. 7 (1949), and id: pt. 2 (section-by-section summary) (March 11, 1949). The Committec adopted the S. 138 provision which imposed 2 40-year maximum on federal loans for urban redevelopment projects.

"Sce Senate debate on April 14, 19, 20, 21, 1949. A series of foor amendments to the bill were defeated by the Senate. These included an amendment by Senator Bricker to strike out the public bousing and farm housing titles. They also included a series of eight amendments to the public housing title offered by Senator-Bricker, either alone or with:Senator Cain, which would have crippled or severely limited that program. In contrast, the only limiting amendment to the urban redevelopment provisions offered by the two Senators was one which would have required the Housing Administrator to obtain loan funds through the appropriations process, instead of by borrowing directly from the Treasury.

495 Conc. Rec. 4852 (1949). Compare the House debate on H.R. 4009, 81st Cong., 1st Sess. (1949), 95 CoNc. Rec. 8128-67, 8223-69, 8341-84, 8451-82, 8534-60, 8615-87 (1949).

"See House Comm. on Banking and Currency, Housing Act of 1949, H.R. RER. No. 590, 81st Cong." Ist Sess. (1949). Again, public attention was directed chiefly to the low-rent housing provisiuns, H.R. 4009 having proposed $1,050,000$ dwelling units over a period of years instead of 810,000 units as in the 
On June 7, the House Rules Committee voted seven to five to table the bill. Its rpposition, as the year before, was centered on the public housing provisions. However, earlier actions taken by that Committee to block floor consideration of bills (such as the Taft-Ellender-Wagner bill) which had strong majority support in the House as a whole had led to the adoption of simplified procedures, which were in effect during the Eighty-first Congress, for bringing a bill to the floor of the House without the concurrence of the Rules Committee. Under threat of resorting to these procedures, proponents of H.R. 4009 persuaded the Rules Committee to reverse itself, and on June I6, the Committee voted eight to four-to send the bill to the floor of the House.

The House debated the bill for several days, starting on June 22. As expected, the major attack was on the low-rent public housing provisions, which were narrowly sustained by a roll call vote of 209 to $204 .^{47}$ The entire bill was then passed on June 29 by a vote of 227 to $186 .^{48}$

At no time during the debate were the urban redevelopment provisions seriously endangered. Representative Cole of Kansas (later to become the Housing Administrator and a strong proponent of urban redevelopment) offered an amendment to prohibit federal aid for urban redevelopment in any fiscal year uniess the Secretary of the Treasury has estimated that the federal government's income for the year would not be less than its expenditures. This amendment was defeated by a division vote of 133 to I06. $^{48}$ Representative Phillips of California offered an amendment which would have required urban redevelopment loan funds and public housing annual contributions to be specifically authorized by Congress in appropriation acts before the federal government could enter into contracts to provide these forms of assistance. This amendment was defeated by a division vote of 131 to $1190^{50}$

Congressional action on the bill was completed on July 8 , when the House and Senate each approved the Conference Report ${ }^{51}$ resolving the few remaining differ-

Senate-passed bill. Differences in the urban redevelopment title between the House-reported and Senate bills were very minor, except that the House bill did not contain a provision, which had been added to the Senate bill by a floor amendment, requiring a public hearing prior to land acquisition by the local public agency. This difference was later eliminated by a House foor amendment which added a similar requirement to the House bill.

${ }^{47}$ Roll Call No. I17, 95 Conc. Rec. 8667 (1949). Prior to this vote, the House, sitting as a Committee of the Whole House, had approved an amendment offered by Chairman Spence to reduec the public housing authorization to 810,000 units, the same number proposed in the Senate-passed bill (95 CoNG. Rec. 8623-36 (1949)). However, the technical effect of the roll call vote was to retain in the bill as passed the 1,050,000 unit authorization proposed in the bill as introduced and reported.

${ }^{48}$ Roll Call No. 120, 95 CoNG. Rec. 8677 (1949\%. See also Roll Call No. r19, ibid., rejecting a motion to recommit the bill and to substitute other legislation which included urban redevelopment, but not public housing, provisions. The bill was debated on June $22,23,24,27,28$, and 29 .

t95 Cong. Rec. 8548 (1949).

oo Id. at 8549 . Similar proposals in the field of housing and urban renewal have been made from time to time by the Eisenhower Administration.

${ }^{82}$ Committec on Conference, Conference Report on Honsing Act of 1949, H.R. REP. No. 975, 8rst Cong., xst Sess. (1949). The bill number was S. 1070, the House having inserted the text of H.R. 4009 as approved by the House after the enacting clause of S. 1070 as previously passed by the Senate. The diffes_nees confronting the conferees were relatively minor, as a practical matter, because the House 
ences between the two chambers. The Housing Act of 1949 was approved by the President on July 15, thereby ending a four-year struggle for enactment. During the history of this legislation, the major change in the basic proposal was the substitution of federal short term loans and capital grants, in connection with cleared land which would generally be sold by the local public agency, for long-term loans and annual subsidies payable over a long period of years, in connection with land which would generally be leased.

A number of factors had contributed to the length and intensity of the struggle. The most basic was that the opposing forces outside Congress were both highly influential and firmly committed to their positions. Organizations supporting the omnibus legislation included many civic, professional, municipal, religious, veteran, and labor organizations. ${ }^{51 \mathrm{a}}$ Often, when legislative support is so widespread, it is also listless and intermittent. In this case, the supporting groups made an unusually sustained and vigorous effort in close cooperation with each other. Factual data and arguments were provided by the professional and municipal organizations and by the Executive Branch of the federal government. General public interest in housing and slum clearance legislation dated to the $193^{\circ}$ 's, but much wider interest was sparked and fanned by the severe nationwide housing shortage which prevailed during the years following the war. This shortage had resulted from the depression, wartime construction limitations, and construction material shortages immediately after the war. The housing shortage was universally recognized as a national emergency because of its special impact on returning veterans. Although this temporary emergency was not relevant to most of the omnibus legislation and although it actually furnished an argument against the slum clearance provisions, it was dealt with by some of the other provisions in the Taft-Ellender-Wagner bill, and during 1947 and 1948 (before these other provisions were separately enacted in the Housing Act of 5948 ), it added very volatile fuel to what might otherwise have been a slow-burning fire.

Objections to the comprehensive housing legislation as a whole, and particularly bitter objections to the public housing provisions, were expressed by every national trade organization whose members were primarily engaged in producing, financing, or dealing with residential property. Although these organizations were handicappei by a "selfish special interest" label which was repeatedly pasted on them by the sponsors of the legislation and by President Truman, they nevertheless had certain counter-balancing advantages which were inherent in their being large yet specialized trade organizations. These advantages included their ability to co-

had already indicated by its vote on the Spence amendment that it would accept the 8ro,000 low-rent housing units proposed in the Senate bill in place of the larger number of units approved by 2 narrow margin on the floor of the House. See note 47 supra. The conferees agreed to the elimination of a provision added on the floor of the House which would have required that preference in the selection of tenants for dwellings built in a redevelopment project area be given to families displaced from the area who were willing and able to pay the rents or prices charged for the new dwellings.

512 Sec note 20 supra. 
ordinate their efforts even more closely than their opponents could; to mobilize local chapters and members more quickly; to testify on the basis of their detailed and practical knowledge of their own industries; and to concentrate all their legislative activity in this one field. Notwithstanding these advantages and the substantial support which they received from the United States Chamber of Commerce and the National Association of Manufacturers, the several trade associations could not muster a majority of Congress on their side, particularly when the extremely wide public support which existed for the legislation was periodically intensified by bluntly worded presidential statements. ${ }^{32}$

Accordingly, the immediate cause for the long delay in enacting the legislation must be sought inside the Congress. The major obstacles to enactment were erected in the House of Representatives rather than in the Senate. These obstacles are readily traceable to the power to delay legislation which the House Committee on. Rules and committee chairmen are able to exercise under the rules of the House. Important traditional factors in selecting Rules Committee members are seniority, which is often obtained by representing "safe" or conservative districts, and the greater ability to withstand public pressures which is afforded to Representatives from such districts. Accordingly, the Committee's power tends to be exercised on the conservative side of issues. Because "safe" districts are often rural districts, committee chairmen and Rules Committee members from such districts are especially likely to excrcise their power against controversial legislation which is designed to meet problems peculiar to urban centers.

The fact that the House as a whole has many members who, unlike Senators, represent areas without any substantial urban centers, helps account for the fact that the Housing Act of 1949 passed the House by a vote of only 227 to 186 , whereas it passed the Senate by a vote of fifty-seven to thirteen. A reading of the House debateon the Housing Act of 1949 confirms the existence of strong feelings by some rural congressmen against legislation to meet the special needs of city dwellers. ${ }^{53}$ Contact

\footnotetext{
${ }^{2}$ See the following statements by President Truman calling for enactment of comprehensive housing legislation, including urban redevelopment provisions: Message from the President Transmitting Outlineof Plans Made for Reconversion Period, H.R. Doc. No. 282, 79th Cong., 1st Sess. 18-20 (1945); Message. from the President of the United States Communicated to Congress, H.R. Doc. No. 398, 79th Cong., 2d Sess. 34-35 (1946); Address of the President Before Congress, H.R. Doc. No.- I, 8oth Cong., Ist Sess.. 6-7 (1947); Veto Message on Housing and Rent Control Act of 1947, H.R. Doc. No. 370, 8oth Cong., 1st Sess. (1947); Midyear Economic Report of the President, H.R. Doc. No. 409, 80th Cong., ist Sess. 44 (1947); Message from the President of the United Stases Transmitting Program for Rent Control and Housing Legislation, H.R. Doc. No. 547, 8oth Cong., ad Sess. (1948); Address of President of United States on Urgent Need to Check Inflation and Meet Housing Shortage, H.R. Doc. No. 734, 8oth Cong., 2d Sess. (1948); Statement on Approval of Housing Act of 1948, Aug. 1o, 1948; Address of thePresident Before Congress, H.R. Doc. No. 1, Bist Cong., Ist Sess. 6 (1949); Econonic Report of the President, H.R. Doc. No. 36, 81st Cong., ist Sess. 6, 16 (1949); 95 CoNG. Rec. 144-45 (1949); id. at 8279-82.

in For example, note the following statements: Congressman Vursell of Illinois: "Mr. Speaker, the $\$ 1,500,000,000$ provided for in the bill for slum clearance will go, most of it; for the purchase of land in the hear of the big cities like Chicago, New York, and several other big cities. . . Mr. Speaker, now after ... e city administrations and city politicans through the years have brought about these slum conditions because of neglect of their duty, and by waste and extravagance of public funds, the raxpayers in.
} 
with urban problems and voters may also account for the fact that forty-two state governors had endorsed the legislation. ${ }^{34}$

A question may be raised as to whether the enactment of the urban redevelopment legislation was hastened or delayed by its inclusion in omnibus housing bills. To attempt to answer this question is to step into the quicksands of speculation. It is clear that the omnibus housing legislation was long delayed by the inclusion of public housing provisions; it is also a matter of record that some of the opponents of the omnibus legislation actually favored federal aid for urban redevelopment and that even the objections which were made to such aid ranged from expressions of mild doubt, through criticism only of detailed provisions, to relatively moderate opposition to the entire program. It is entirely reasonable to conclude that the omnibus legislation, including urban redevelopment provisions, would have been enacted much sooner if the public housing provisions had been abandoned; and several definite opportunities to achieve this result occurred during the history of the legislation. However, an entirely different question is presented if we attempt to judge how long it would have taken urban redevelopment provisions to be approved by Congress if they had not been combined with any other proposals. The support for urban redevelopment legislation was widely based, but it is difficult to estimate how intense this widespread support would have been if the legislation had stood alone. Perhaps only planners and municipal officials would have given it sustained and vigorous support during the I940's. Similarly, while we know that the opposition to the urban redevelopment provisions in the omnibus legislation was relatively moderate, it is difficult to judge how intense it might have become if public housing provisions had not been attached, diverting so much hostility in their direction. With so many unknown factors, it seems to us futile to speculate concerning the time when an urban redevelopment program might bave been enacted had it been offered in a separate bill.

No summary of the four-year battle over the omnibus housing legislation would be complete without some reference to the character of the fighting-and in-fighting. Opponents of the legislation accused the proponents of being socialistic or power-

my district of southern Illinois, who have worked and saved to build their own homes, are called upon after they have paid their own taxes and kept their own homes in livable conditions, to contribute money in taxes and rentals ...." 95 Cosc. Rec. 7387 (r949). Congressman Herbert A. Mejer of Kansas: "Now what about the slum-clearance angle? Will these projects help in any way in coutheastern Kansas? The answer is 'No; they will not: The one and one-half billion' dollars provided for slum clearance will be used mostly for the purchase of land in the heart of big cities such as Chicago, Ner York, ctc. ... If this legislation is passed the lowly taxpayers of southeastern Kansas will also have to contribute to the rebuilding of slums in New Jersey:" Radio Address inserted in 95 CoNG. Rec. A3883 (1949). Congressman Scudder of California: "I feel that the slum-clearance program contained in this bill will not in any way benefit the first Congressional District [California] which is predominant;: agricultural and with many small cities. With very few exceptions these small cities are inhabited by people who take pride in keeping up their homes regardless of how meager their means might be. Slums, in my opinion, aze largely made by the people who live in them. . . . I feel the people in my district should not be compelled to pay the rentals for people residing in the large metropolitan areas." 95 Covc. REC. 8663-64 (1949).

* 95 CONG. REC. $81=8$ (1949). 
hungry or demagogic. Proponents charged that the trade association members who opposed the legislation were either misled by their own hired executives or lobbyists or else were selfishly placing the chance for private profits ahead of the public welfare. It is the confident judgment of the writers-who are personally acquainted with many of the combatants on both sides-that each side was wholly sincere in its conviction that its basic position was in the public interest and that each side harbored sincere suspicions that the other side was cynically motivated. These mutual suspicions were fed by the exaggerated claims made by both sides-the proponents with respect to how very much could soon be accomplished under the legislation, and the opponents with respect to the ability of private enterprise quickly to solve long-standing and severe housing problems without federal aid. However, there was a small but not insignificant minority of the spokesmen against the omnibus legislation who were more prone than other combatants on both sides to present factual data carelessly or out of context. Unlike exaggerated general claims which merely tend to be discounted, this last weapon tended to boomerang. ${ }^{\$ 5}$

\section{III}

\section{The 1949 ACt AND AMENDMENTs 56}

\section{A. Original Provisions}

As explained in part I of this article, the major outlines of Title I of the I949 Act were essentially the same as proposals made in 1941, except as to the type of federal subsidy involved. Basically, Title I authorized financial assistance by the Housing and Home Finance Administrator to a local public agency for a project ${ }^{67}$ consisting of the assembly, clearance, site-preparation, and sale or lease of land at its fair value for uses specified in a redevelopment plan for the area of the project. The project could not include the construction or improvement of any buildings contemplated by the redevelopment plan. ${ }^{58}$

Advances of funds to the local public agency were authorized for surveys and plans in preparation of the project, and temporary loans were authorized for land acquisition and other project costs, these loans to be repayable when the land was sold or leased for redevelopment. Long-term loans, up to forty years, were authorized with respect to the portions of any sites to be leased. .8* $^{\text {s. }}$

Capital grants were authorized to help meet the loss involved in connection with

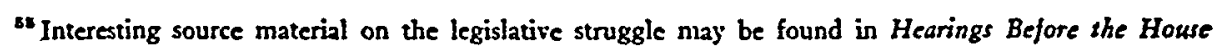
Select Commitree on Lobbying Activities, 81st Cong., 2d Sess. (1950). A brief but informative statement by Housing Administrator Foley on legislative activities of the Housing and Home Finance Agency may be found in id. pt. 10, Legislative Activities of Executive Agencies, at 39-46.

se The provisions of Title I of the 1949 Act and summaries thereof are, of course, available at many sources, and, accordingly, the title will not be summarized in detail herc. Provisions relating to subjects discussed in part IV of this article are explained in that part.

"See "The "Predominantly Residential' Requirement," infra at IV $(\Lambda)$.

"In connection with any project on land which was open or predominantly open, the Housing Administrator was authorized to make loans, up to to ycars, for the provision of public buildings or facilities necessary to serve the new uses of such land.

sta See note 7 supra. 
the project. ${ }^{58}$ The federal grants could not exceed two-thirds of the losses on all of these projects in the locality. The local government or other public body or entity had to furnish "grants-in-aid" equal to at least one:third of such losses. These local grants-in-aid could be in the form of cash, donation of land, the use of municipal labor and equipment to clear a project area, or the installation of streets, utilities, and other site improvements, or they could be made through the provision of parks or schools or other public facilities necessary to serve or support the new uses of land in the project areas.

An outline of the method of financing an urban redevelopment project under the act can be indicated by the following table::00

A. Gross project cost.

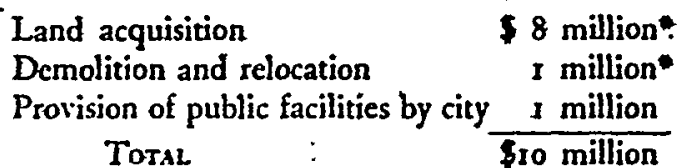

* Financed by $\$ 9$ million of federal or private loans (planning costs excluded for purposes of simplicity)

B. Proceeds from sale of land $\ldots \ldots \ldots \ldots \ldots \ldots \ldots \ldots \ldots \ldots \ldots \ldots \$ 4$ million

C. Net project cost ................................... \$ 6 million

D. Grants :

\begin{tabular}{lc} 
Federal grant of $2 / 3$ net cost \\
Local grant of $1 / 3$ net cost: \\
$\begin{array}{c}\text { Cash grant } \\
\begin{array}{c}\text { Provision of public facilities } \\
\text { by ciry }\end{array}\end{array}$ & $\$ 4$ million \\
Tors & $\frac{1 \text { million }}{\text { million }}$ \\
\hline 66 million
\end{tabular}

E. Loans repaid from:

\begin{tabular}{lr} 
Proceeds of sale of land & $\$ 4$ million \\
Federal grant & 4 million \\
Local cash grant & 1 million \\
\multicolumn{1}{c}{ Total } & $\$ 9$ million
\end{tabular}

It was prescribed in the 1949 Act that contracts for loans or capital grants must require that: (x) the redevelopment plan be approved by the governing body of the locality; (2) the local governing body find, among other things, that the plan conforms to a general plan for the development of the locality as a whole; (3) the purchaser or lessee of the land be obligated to devote it to the uses specified in the redevelopment plan and to begin building his improvements on the land within a

ot This loss, known as "net project cost," consisted of all project expenditures, plus the amount of non-eash local grants-in-aid, minus the proceeds of land disposition.

${ }^{60}$ The amounts used in this table are not intended to indicate average or typical amounts, but are assumed solely for purpose of simplicity. 
reasonable time; (4) there be a feasible method for the temporary relocation of families displaced from the project area and for the permanent provision of decent, safe, and sanitary dwellings at prices and rents within the financial means of such families; and (5) none of the project land will be acquired by the local public agency until after a public hearing. ${ }^{61}$

The 1949 Act authorized \$ billion in federal loans and $\$ 500$ million in federal grants to become available over a five-year period. The grant authorization has been increased from time to time until it is now \$2 billion." It has become the measure of the volume of the program authorized by the Congress. This is so because the loan authorization is a revolving fund which is replenished as loans are repaid when projects are completed. Also, in some cases federal grants are used for projects without federal loans. ${ }^{\text {es }}$

\section{B. The 1954 Revision}

The urban redevelopment legislation was not substantially changed until the Housing Act of $1954^{64}$ The revision in that act was primarily the result of recommendations by President Eisenhower's Advisory Committee on Government Housing Policies and Programs in its report made in December 1953. The dominant recommendations in this extensive report dealt with urban redevelopment. The principal motivations for these recommendations were apparently the desire of the Committee (I) to have private enterprise do a greater share of the total job of removing and preventing blight, especially through rehabilitation of existing structures; (2) to require cities to take greater responsibilities for meeting their over-all problems of slums and blight; and (3) to stimulate private residential redevelopment and the provision of private low-cost housing for families displaced by urban redeyelopment and other governmental activities.

The basic change recommended was a shift from urban redevelopment to "urban renewal," which was then a term without common usage. It was described as a broader and more comprehensive approach to the probtems of slums and blight, or as a redirection of the urban redevelopment program. More specifically, it meant a broadening of the program into blighted areas where the land would not be acquired by the local public agency. This was intended to permit blight in the area to be eliminated by private enterprise through rehabilitation, so that structures would be conserved before reaching a stage where demolition would be necessary.

\footnotetext{
"See article in 'his symposium, Rhyne, The Workable Program-A Challenge for Community Im. provement, infra at 685 , as to requirements relating to building and other local codes and regulations.

22 103 (b) of the Housing Act of 1949 , 306(a) of the Housing Amendments of 1955, 5301 of the Housing Act of 1957, $5405(1)$ of the Housing Act of 1959, 73 Stat. 672, 42 U.S.C.A. 5 J453 (Supp. 1959).

"Such projects, involving no contract for federal loans, must be distinguished from the typical projects where (as specifically authorized by 102 (c) of the Housing Act of 1949, 63 Stat. 414, 42 U.S.C. 1452 (c) (1958)) most of a federal loas is not disbursed because substitute private funds are obtained, with consent of the Housing Administrator, on better terms with a pledge of the federal loan contract. Af present, just under $90 \%$ of the outstanding loans for projects are private rather than federal.

“68 Stat. 5yu, 622, 42 U.S.C. 551451 et seq. (1958).
} 
This was also intended to make the federal dollar go farther, as rehabilitation involved far less cost, especially to the federal government, than land acquisition and demolition. Most important of all, it was recognized that the vast job which needed to be done could not possibly be done solely through the very expensive method of clearance.

Major provisions of the 1954 Act relating to urban renewal are discussed in detail in other articles in this symposium. For purposes of this article, the writers believe it best merely to enumerate the following:

1. Urban Renewal. "Urban renewal" was substituted for "urban redevelopment," and the Title I program under the 1949 Act was broadened as recommended by the President's Advisory Committee. An urban renewal "project" was defined to include not only the previously authorized acquisition, clearance, and disposal of land by the local public agency, but the restoration of other blighted or deteriorating areas by "carrying out plans for a program of voluntary repair and rehabilitation of buildings or other improvements in accordance with the urban renewal plan." ${ }^{\text {"es }}$ An urban renewal project can be all redevelopment, or all rehabilitation, or a combination of the two.

Project functions which previously could be exercised by the local public agency on the land it aequired, such as installation of streets and utilities, were authorized to be exercised throughout the urban renewal area. This included the acquisition of individual parcels in a rehabilitation area for the purpose of demolishing the buildings if necessary to eliminate unhealthful conditions. lessen density, eliminate obsolete or other detrimental uses, or to otherwise remove or prevent blight or deterioration.

2. The. Workable Program. Section 303 of the $1954 \mathrm{Act}^{86}$ prohibited any loan and grant contract for an urban renewal project until the locality pre: sents to the Housing Administrator a "workable program" or plan of action for meeting its over-all problems of slums and blight and of community development generally. This program was also made a condition to federal financial assistance for low-rent public housing and for the new special FHA mortgage insurance programs authorized in the 1954 Act to assist urban renewal. The article in this symposium entitled "The Workable Program-A Challenge for Community Improvement" discusses the meaning, legislative history, and effect of this provision.

3. Special Miortgage Insurance Programs. Section 123 of the $1954 \mathrm{Act}^{07}$ added new sections 220 and 221 to the National Housing Act to make FHA mortgage insurance available on liberal terms for private residential construction which would assist in meeting the objectives of the urban renewal program. The section 220 aid is available for new or rehabilitated sales and rental housing in

"* 68 Stat. 626, 42 U.S.C. 1460 (5) (1958).

* 68 Stat. 623, 42 U.S.C. 51451 (1958).

${ }^{\circ} 68$ Stat. 596, 12 U.S.C. 5 1715k, 1 (1958). 
urban rencwal areas. The section 221 aid is available for these categories of housing provided for families displaced by urban renewal or other government action, and the housing may be locatcd within an urban renewal area or clsewhere in the community. Because the purpose of section 220 is to encourage renewal of project areas for their most suitable housing use, which is not necessarily low-cost housing, section-220-insured mortgages may be considerably larger in amount per dwelling unit than mortgages insured under section 221, which is designed to serve displaced persons who are generally of low or moderate income. These sections have been extensively amended from time to time for the purpose of increasing their use and effectiveness.

$A$ basic factor in making these mortgage insurance programs workable was another provision in the $1954 \mathrm{Act}^{\text {tS }}$ establishing the Special Assistance Functions of the Federal National Mortgage Association under which it was contemplated that mortgages insured by FHA under sections 220 and 221 would be purchased by the Association when not readily acceptable to private investors. The mortgages were made, and remain, eligible for purchase under the Special Assistance Functions.

4. Matching Planning Grants. Section 701 of the act ${ }^{69}$ established a new prugran of federal matching grants (a) to state planning agencies for planning assistance to cities of less than 25,000 population, and (b) to state, metropolitan, and regional planning agencies for planning in metropolitan or regional areas. This section has been considerably expanded by a series of amendments.

5. Demonstration Grants. The act ${ }^{30}$ authorized the Housing Administrator to make grants (from urban renewal capital grant funds) to cities and other public bodies to pay for up to two-thirds of the cost of developing, testing, and reporting methods and techniques, and carrying out demonstrations and other activities, for the prevention and elimination of slums and urban blight.

6. Exception from Residential Reguirement. The act ${ }^{73}$ made the first exception from the requirement that an urban redevelopment area must either be predominantly residential in character or be redeveloped for predominantly. residential uses. An exception up to ten per cent of the total grant authorization was made for areas which are not appropriate for residential development, but contain a substantial number of slum, blighted, or deteriorating dwellings or other living accommodations, the elimination of which would tend to pro mote the public health, safety, and welfare. (Land not to be cleared and redeveloped was not made subject to the "predominantly residential" requirement by the 1954 Act.)

6n 68 Stat. 616, 12 U.S.C. \& 1720 (1958).

688 Stat. 640, 40 U.S.C. ${ }_{461}$ (1958).

${ }^{70} 68$ Stat. 629,42 U.S.C. 14522 (1958).

1168 Stat. 627, 42 U.S.C. S1460 (1958). 
7. Urbun Renewal Service. The Housing . Idministrator was authorized to establish facilities for furnishing an "urban renewal service" to communities to assist in the preparation of "workable programs" and to provide them with technical and professional assistance for planning and developing local urban renewal operations. ${ }^{72}$

8. Public Hotsing for Urban Renewal. The additional low-rent public housing units authorized by the 1954 Act were made available only for meeting the needs of families displaced by governmental activities in a community where an urban redevelopment or urban renewal project was being carried out. ${ }^{73}$ - '

The 1954 Act applied the same financing provision to rehabilitation as applied to clearance and redevelopment. The following table $e^{74}$ illustrates the application of the capital grant formula to both:

\section{Urban renewal
Project Activitics
project comprising solely redevelopment}

Surveying and planning

Land acquisition.

............... \$ 25,000

Demolition, clearance, and relocation....... . 50,000

Installation of streets, sewers, water improvements, parks, etc............. 200,000

Cirrying out plans for a program of

voluntary rehabilitation and repair

of buildings.

Gross project cost

Proceeds derived from sale

of project land

Net project cost

$$
\frac{525,000}{750,000}
$$$$
\$ 1,275,000
$$

500,000

Local cash grant-in-aid

Capital grant, $\frac{2}{3}$ of net project cost.

$\$ 250,000$
Urban resewal project comprising solely rehabilitation (assumes a larger arca)

$\$ 25,000$

none

none

$\frac{5,000}{\$ 750,000}$

\section{Other Amendments}

One of the most significant developments in the amendments following the r954 Act related to urban renewal planning on a wider scale than the areas of specific

7* 68 Stat. 624, 42 U.S.C. 5 1451 (1958).

: This limitation on low-rent public housing was repealed by $\$ 108$ of the Housing Amendments of 1955, 69 Stat. 638.

is Prepared by Urban Renewal Administration. See Hearings Before the Senate Commiflee on Banking and Cumency on Housing Amendments of 1956, 84th Cong., 2d Sess. 151 (1956). 
projects about to be undertaken. The need for this broader type of planning was recognized in section 303(d) of the Housing Act of $1956{ }^{7 \pi}$ which authorized the Housing Administrator to make advances to local public agencies for the preparation of General Neighborhood Renewal Plans for urban renewal areas of such scope that the urban renewal activities in the areas may have to be carried out in stages, over a period of not more than ten years, rather than as a single project. These Plans are preliminary plans outlining proposed urban renewal activities and providing a framework for the later preparation of several specific urban renewal plans. The advances for these Plans become repayable out of funds becoming available to the local public agency for the first urban renewal project in the area.

The Housing Act of $1959^{76}$ authorized assistance for a much broader and more significant form of urban renewal planning-the preparation of long-range "community renewal programs," or preliminary plans with respect to all of the urban renewal needs of a city. The Housing Administrator was authorized to make grants for this planning, instead of advances. These grants may be made, up to two-thirds of cost, for the preparation of community-wide plans which include identification of slum or blighted areas in the community, measurement of blight, dete'mination of resources needed and available to renew the areas, identification of potential project areas and types of action contemplated for each, and scheduling of urban renewal activities. This enables more effective use of federal and local funds by permitting the best scheduling of urban projects in the community. Eventually it may also help to furnish information on a national basis concerning urban renewal needs. It may be noted that community-wide renewal plans can encompass work previously authorized to be done with the aid of federal advances for General Neighborhood Renewal Plans and for surveys as to the feasibility of individual projects. However, the Congress did not repeal the earlier authority for advances to assist such Plans and surveys.

Other significant amendments enacted since the 1954 Act have made federal funds available to local public agencies to compensate (if not otherwise compensated) individuals, families, and businesses for reasonable and necessary moving expenses and any direct losses of property, except good will, resulting from displacement by an urban renewal project. ${ }^{73}$ This was done in recognition of the fact that state eminent domain laws do not generally provide adequate compensation to all the persons materially affected by the public taking of property. The federal government bears one hundred per cent of the cost of these payments instead of the ustual twa-thirds of project costs. The Housing Act of $195^{78}$ permitted payments up to $\$ 100$ in the cases of an individual or family, and up to $\$ 2,000$ in the case of a business concern. The maximum statutory amount of these payments is now $\$ 200$ in the

"75 70 Stat. 1097, 42 U.S.C. 51452 (d) (1958).

${ }^{30} 73$ Stat. 672, 42 U.S.C.A. I $_{453}$ (Supp. 1959).

$" 7$ See note I supra.

74 70 Stat. 1100 . 
case of an individual or family and $\$ 3,000$ in the case of a business concern. ${ }^{70}$ There has been almost continuous pressure in Congress further to increase these amounts, particularly the amount of payments to businesses, which may have actual moving expenses several times such amount. Legislation pending in the Eighty-sixth Congress when it recently adjourned would provide further increases. ${ }^{80}$

$U_{p}$ io the present time, urban renewal amendments have each year constituted one of the principal parts of omnibus housing legislation considered by Congress. For example, the lengt: of the urban renewal amendments in the Housing Act of I959 is about the same as the lerigth of the original Title I of the 1,949 Act. Other extensive amendments in the 1959 Act deal with programs having a direct relation to urban renewal, such as mortgage insurance for urban renewal housing, purchas: of the mortgages by the Federal National Mortgage Association, and urban planning.

In addition to increases in grant authorizations there has been a general trend in the amendments toward greater federal benefits and more local discretion ${ }^{82}$ in the urban renewal program. For example, the 1959 Act (Title IV):

x. permits a community to count as a local grant-in-aid any eligible local public improvement started within three years prior to the execution of a loan and grant contract for the urban renewal project;

2. increases the maximum amount of relocation payments to persons and businesses displaced by urban renewal, and broadens the scope of those eligible for payments;

3. authorizes grants for community-wide urban renewal planning;

4. authorizes temporary loans, under certain conditions, for land acquisition by a local public agency before it is known that an urban renewal plan will be approved;

5. permits expenditures by a college or university in purchasing and clearing property near an urban renewal project to be counted as a local grant-in-aid, and waives the "predominantly residential" requirement in such cases;

6. defines the loans chargeable to the dollar. limit on the urban renewal borrowing authorization in such a way as to make remote in time any restriction of lending activities by the limit; ${ }^{82}$

7. prohibits withholding available federal funds from an eligible urban renewal project except on the basis of urgency of need or feasibility of the project;

${ }^{70} 73$ Stat. 674,42 U.S.C. $\$ \$ 1456$ (f) (Sipp. 1959).

${ }^{80} \mathrm{Sec} \$ 80 \mathrm{r}(\mathrm{a})$ of H.R. 12603, 86th Cong., 2d Sess. (1960) as reported by the House Committee on Banking and Currency, and $\$ 4^{03}$ of S. $3670,86 \mathrm{th}$ Cong., 2d Sess. (1960), as passed by the Senate.

${ }^{81}$ One new restriction, $\$ 407$ of the 1959 Act, 73 Stat. 673, 42 U.S.C.A. $\$ 1455$ (Supp. 1959), prohibits any commitment for disposition of project land to a redeveloper unless the local public agency makes public certain information relating to the sedeveloper and relating to any scsidential redevelopment or rehabilitation.

${ }^{2}$ The $\$ r$ billion ceiling on funds which can be borrowed from the Treasury for urban renewal loans is now applicable only to outstanding federal loan funds disbursed or committed and estimated to be disbursed from federal funds in the future, as of any one time under existing contracts. Under the law prior to the 1959 amendment, it applied to all loan funds contracted for without regard to whether they would ever be disbursed. The ratio of disbursed loans outstanding to private loans secured by the federal loan contracts bas been as low as about I to 10 . 
8. increases the amount of authorized exceptions from the requirement that an urban renewal project area be predominantly residential in character before redevelopment or else be developed for predominantly residential uses; and

9. simplifies the statutory requirements for an urban renewal plan.

Perhaps the most significant and novel proposal embodied in urban-renewal: legislation considered in the recent Eighty-sixth Congress was an amendment to enable a local public agency to carry out "pilot" rehabilitation efforts in urban renewal project areas. This amendment, contained in both the House and Senate versions of the "Housing Bill of $1960 " 83$ (which were pending when the Eighty-sixth Congress adjourned), would permit the local public agency to acquire a few dwellings, rehabilitate them as part of the urban renewal project at project expense, and sell them to private owners. The number of these dwellings involved in an urban renewal area could not exceed-fifty dwelling units, nor two per cent of the number of units which are to be rehabilitated under the urban renewal plan. The proposal contemplates that the local public agency will, through this undertaking, demonstrate to property owners in the area that rehabilitation is feasible.

The Housing and Home Finance Agency has enthusiastically supported this proposal as a means of getting rehabilitation under way in urban renewal areas. ${ }^{84}$ Rehabilitation of substantial numbers of existing houses in urban renewal areas has been carried out successfully in only a few cases; so that this important phase of urban renewal has been lagging. The Agency indicated that the "pilot" efforts should go a long way toward stimulating property owners to rehabilitate their properties.

As this proposal.would permit certain rehabilitation:work on buildings to be part of an urban renewal-project, it would be the first exception, as a technical matter, from the prohibition in the 1949 Act against a project including construction or improvement of any building. ${ }^{85}$ In principle, however, the proposal would not be a departure from the purposes for which federal grants are now used. As the proposed rehabilitation would serve as a demonstration for property owners throughout the urban renewal area, it would be similar in this respect to schools and other public buildings which serve the project. The costs of these buildings are counted as local grants-in-aid and are included in gross.project cost and increase federal grants accordingly.

\section{IV}

\section{Two RecurRing Issues}

Although the two issues discussed in this part are not perhaps the most important issues in federal urban renewal legislation, they were selected for discussion because

is 503 of H.R. 12603, 86th Cong., as reported by House Committec on Banking and Currency, and 405 of S. 3670 , as passed by the Senate.

"Hearings. Before the Sanate Commitice on Banking and Currency on Housing Legislation of rg6o, 86th Cong., 2d Sess. 990. (1960).

${ }^{85} 63$ Stat. 420,42 U.S.C. S.1460(c) (1958). 
each is important, currently controversial, has a way of appearing and reappearing in varying forms and disguises, and is not likely to be finally settled soon..$^{86}$

\section{A. The "Predominantly Residential" Requirement}

Tirle 1 of the 1949 Act included a provision designed to direct federal urban redevelopment aids toward the betterment of housing, as distinguished from the betterment of cities and urban life in general. In effect it limited an urban redevelopment project area to one "which is predominantly residential in character" before redevelopment or "which is to be developed or redeveloped for predominantly residential uses." and is the law today with exceptions and modifications discussed below. The enactment of these exceptions and modifications over a period of time reflects the fact that the requirement has continued to be one of the most important live issues in the field of urban renewal legislation.

The expression "predominantly residential" has had such general and frequent usige throughout the operations under Title I that some have come to regard it as a reference to an inherent characteristic of the program. Yet, it was not mentioned in the earlier urban redevelopment proposals and is not a common concept in state laws authorizing urban redevelopment or urban renewal projects.

The principal early advocates of a federal urban redevelopment program, the planners, did not approach it from the standpoint of housing. Their major objective was redevelopment in accord with a general plan for the entire urban area. Slums were treated as but one important phase of urban blight, and housing as but one important form of redevelopment. ${ }^{88}$ This position was forcefully presented before the Taft Subcommittee by Seward H. Mott, Director of the Urban Land Institute, and Alfred Bettman, representing the American Institute of Planners. ${ }^{89}$ The latter's statement included::0

... a serious warning needs to be issued against conceiving urban redevelopment as a subject identical with housing of housing with little variations-housing the theme, urban redevelopment the variations. Of the uses of the land of an urban area, habitation is the largest, running, I believe, from 60 to 75 percent; but this is just as true of the unblighted as of the blighted areas, of the whole urban territory as of the blighted portion thereof. So, while housing construction will always form the larger proportion of all urban re-

- See note I supra.

"I $110(c)$ of the 1949 Act defined "project" to include "acquisition of (i) a slum area or * deteriorated or deteriorating area which is predominantly residential in character, or (ii) any othet deteriorated or deteriorating area which is to be developed or redeveloped for predominantly residentia uses, or (iii) land which is predominantly open and which because of obsolete platting, diversity of ownership, deterioration of structures or of site improvements, or otherwise substantially impairs or arrests the sound growth of the community and which is to be developed for predominantly residential uses, or (iv) open land necessary for sound community growth which is to be developed for predominantly residential uses (in which cvent the project thereon, as provided in the proviso of section $103(a)$ hereof, shall not be eligible for any capital grant) ...." 63 Stat. 420 .

"Guy Greer \& Alvin H. Hansen, URrax Redevelopisest asd Housisc (National planning Ass'b. I94r).

Taft Subcommittet Hearings $1602-22$.

18. at 1606 . 
development or development, a costly mistake will be made if urban redevelopment be conceived of as the replanning and rebuilding of slum areas only or the replanning or rebuilding for housing only. The redevelopment or rehabilitation process needs to be applied to all areas which need it and for all the classes of uses which, according to good city planning principles, are appropriate to those areas. As urban redevelopment will prepare areas for reconstruction and will finance this preparation, housing, that is habitation, will be the greatest beneficiary of this process; but unless the legislation, planning and administration be understood to be for all kinds of blighted areas for all classes of urban uses, the process will not produce sound and stable results.

Objection to the above approach was voiced immediately by members of the Subcommittee, especially Senator Taft, who indicated his belief that any urban redevelopment project should involve housing. ${ }^{91}$ He questioned the federal interest in any project going "beyond housing and beyond the elimination of slums." He argued that the federal government was committed to a policy of assisting housing, thereby relieving poverty and hardship, and that federally-aided urban redevelopment for this social welfare purpose was desirable, but projects going further merely improved the looks or financial status of local communities. Mr. Bettman contended, without being able to persuade Senator Taft, that the economic deterioration of cities affects the national economy, thereby justifying federal aid. Near the end of this discussion, the following exchange occurred: $:^{22}$

Senator TAFT. You tried to separate it [urban redevelopment] very clearly from housing. I wonder if there is not an intermediate step, an intermediate possibility? That is, that the federal government might finance the acquisition where, by doing so, they eliminate a comparatively large amount of slum housing, where two-thirds of the place is residential.

Mr. BETTMAN. That is right.

Senator TAFT. In order to do that, you might have to help the city finance a somewhat larger development plan. That seems to me a possible approach to it. I would regard that more favorably than a wide open plan.

Mr. BETTMAN. It would be predominantly housing, because all urban development is predominantly housing.

The Taft Subcommittee report recommended a predominantly residential requirement, saying "The Subcommittee is not convinced that the federal government should embark upon a general program of aid to cities looking to their rebuilding in more attractive and economical patterns." As used here "predominantly residential" was taken to mean over half residential, not two-thirds.

One side-issue involved in the hearings was whether local housing authorities should administer the urban redevelopment program at the local level. The case for them was made by William J. Guste, testifying on behalf of the National Public Housing Conference. He stressed the relationship of urban redevelopment and

"2 Id. at I6ra, 1905 .

2IId. at $16 \times 8$. (Emphasis added.)

os Taft Subcommittee Report os Postwar Housing is (Aug. 1, 1945). 
housing and pointed to the experience of the housing authorities as public bodies equipped to take the local public action needed in the proposed program. ${ }^{04} \mathrm{Mr}$. Bettman had argued that the local planning work in connection with urban redevelopment could be done soundly only by an agency whose sole or primary function is planning, as distinguished from an operating agency, especially one which has an interest in one class of land use such as housing. ${ }^{95} \mathrm{He}$ also suggested that the projects be executed either through an appropriate city department or a specially created local redevelopment agency. ${ }^{90}$ This difference in position represented a division of two groups which were major supporters of urban redevelopment legislation, with the public housing group tending to align itself with those members of Congress favoring the more narrow approach of limiting urban redevelopment projects to those involving housing. ${ }^{\text {.7 }}$

Another side-issue related to the predominantly residential requirement was the major conflict within the Executive Branch as to whether the Federal Works Agency or the Housing and Home Finance Agency should be given the authority to administer the urban redevelopment program. The Federal Works Agency, in January 1949, proposed within the Executive Branch a substitute for Title I or S. 138 , Eighty-first Congress, the Administration-approved proposal for urban redevelopment legislation introduced in Congress earlier in the month. This substitute would have, among other things, eliminated the predominantly residential requirement, and would have placed the program in the Federal Works Agency. The principal argument made for the substitute was that housing constituted only one facet of a realistic urban redevelopment program. The FWA felt that the Administrationsponsored bill took a narrow approach to the problem of urban decay and redevelopment, arbitrarily excluding needed commercial and industrial projects. It was also predicted that efforts to circumvent the predominantly residential requirement would lead to administrative gerrymandering and unsound delineation of projects. ${ }^{98}$

In reply to the FWA's proposal, the Housing Agency contended, to the satisfaction of the Executive Branch:

I. The provisions of the Administration bill did not represent an unduly "narrow" or "restricted" approach, but would (within the framework of what Congress would then accept) meet the bulk of the problem referred to by the

Q2 Taft Subcommittec Hearings 1690.

os Id. at 1609 .

${ }^{96} 7 d$. at 1614 .

-T This does not reflect the presently prevailing views of local public housing authorities, which now often administer urban renewal as well as public housing operations. In generat, representatives of these and of other local public bodies now tend to join in favoring fewer restrictions on federal aids to communities so that there can be greater local autonomy.

${ }^{\circ \theta}$ Objection was also raised to provisions of the Administration bill permitting open land projects if developed for housing use. It was contended that, as slums and blighted arcas would be difficult to clear, funds made available for urban redevelopment would be channeled to the more easily handled open land projects. However, it was explained in reply that open land projects would only supplement a community's slum clearance and urban redevelopment program by helping to provide housing for displaced families. 
Federal Works Agency. Most slums and blighted areas are residential, and also the best new use after clearance would frequently be for housing and its related community facilities. Many blighted business and industrial areas are surrounded by slum areas, so that these could be handled under the bill by including in the project a large enough area of surrounding slums, making the entire area predominantly residential in character. It could then be developed for commercial or industrial purposes where that is appropriate.

2. No substantial portion of the initial program should be diverted from the greatest need-the improvement of the immediate living environment of American families. Projects for other purposes would raise a question as to whether their relationship to the general welfare of the nation warrants federal expenditures in aid of the local objective.

3. The provision of housing for families living in slums cannot be separated from the elimination of the slums. They are both major interrelated problems which must be solved together. At their core are the most delicate and difficult of problems-the housing (or rehousing) of low-income families and minority groups.

In general, the legislative history explaining the predominantly residential requirement enacted as part of the Housing Act of 1949 was in accord with the position of the Housing and Home Finance Agency ${ }^{99}$ In explaining this requirement on the Senate floor, Senator Sparkman said, "Consistent with the findings of earlier congressional studies, the committee felt that the primary purpose of the slum-clearance program should be to help remove the impact of the slums on human lives." It may be noted that, just as groups normally aligned on housing matters split on this issue, members of the Senate frequently in opposition on housing matters were aligned in emphasizing the primary importance of the elimination of substandard housing. The statement of Senator Sparkman not only expressed the views of principal sponsors of the Housing Act of 1949, such as Senators Taft, Ellender, and Douglas, but also the views of Senator Cain, a principal exponent at the time of the most conservative position in the Senate on housing legislation. ${ }^{100}$

Throughout the controversy over the scope of the urban redevelopment program, its relationship to housing was recognized by all, and the differences of position arose from the degree of significance attached to that relationship. To the planners, housing was secondary-to be clearly distinguished from the basic function, the planned redevelopment of cities. To the Federal Works Agency, the urban renewal projects could have become primarily another type of public works, involving planning and engineering techniques similar to those used in other municipal improve-

\footnotetext{
"House Comm. on Banking and Currency, Housing Act of 1949, H.R. REP. No. 590, 81st Cong., 1st Sess. 16-17 (1949); 95 Cong. Rec. $4604,461_{3}$ (1949).

${ }^{100}$ Some proponents of the predominantly residential requirement denicd any justification for federal expenditures solely to eliminate nonresidential blight, whereas others merely contended that housing betterment had a prior claim on limited federal funds.
} 
ments, but with additional housing problems requiring consultation with housing experts. Actually, little was presented to support the separation of urban redevelopment operations in whole or in part from housing operations. Such separation would undoubtedly have been a narrow approach, rather than the broad approach it was alleged to be.

On the other hand, it seems to us that a certain narrowness pervaded most of the discussion and conşideration leading to enactment of the predominantly residential requirement. Urban redevelopment projects were generally viewed as though they existed in some detached or isolated spot. In viewing the housing significance of a redevelopment project, the discussion was focused on what would happen within its physical boundaries and on methods of relocating the residents. There was recognition of the need to conform a project plan to a current master city plan, but members of Congress apparently gave little attention to urban redevelopment as a step in the long and difficult, but continuous, journey toward the redevelopment of the city as a whole. Neither was much thought given by Congress to the potential effect of urban redevelopment on the people of the entire community in their day-ioday life at home, at work, at leisure, and in transit within the city.

There were occasional references in the congressional discussions to the fact that cities are largely made up of residential areas, but this was not offered to show that urban redevelopment would in any event have a residential orientation making unnecessary any statutory requirement relating to the character of the area of each project. Senator Taft made it clear that he felt that federal aid was justified only to avoid the harmful effect of substandard dwelling structures on the people living in them. In an unsuccessful attempt to find some common ground with the Senator, Mr. Bettman, in his very able presentation before the Taft Subcommittee in support of urban redevelopment, was driven to emphasize the role which nonresidential urban redevelopment projects can play in bettering the national economy by checking economic deterioration within cities. The Housing Agency, in an attempt to hasten the enactment of legislation which was politically achievable, often pointed out that most urban blighted areas consist of housing and that most cleared land would generally be used for housing. However, this was generally done in a context of minimizing the problems which would remain if federal aid were denied to projects involving the redevelopment of nonresidential areas for nonresidential uses. The Agency contended that these cases would be few; that federal assistance for them should be deferred; and (crossing over to the shadier side of the street) that in any case, it would frequently be possible to take care of the situation by simply enlarging the area until it becomes predominantly residential. In fairness to all concerned, the narrow tone of the discussions undoubtedly reflected the lack of widely-based popular support for a broader program, it being true that important legislation is not often brought into being by technicians and congressmen and executive officials alone. 
From the vantage point of today, there seems to be widespread agreement that the federal interest in urban redevelopment does not depend strictly on housing betterment as such or on the percentage of a project or program which is residential. Rather, increasing emphasis is being placed on improving the living environment of the urban population, which now includes about seventy per cent of the nation. The close interrelationship of urban renewal to over-all urban development and the close interrelationship of residential development to commercial and industrial development and to public facilities and transportation are now the common currency of popular journalism and editorial comment, and even of casual conversation among suburban commuters. By and large, the views of Congress have kept pace with those of the public and the courts-occasionally in the van and occasionally in the rear, but never very far removed.

A substantial argument could have been made for the predominantly residential recuirement as simply a temporary method of channeling limited available federal funds to the area of greatest need-the slums. This was expressed by the Housing Agency and was implicit in the recommendations of the Taft Subcommittee. As the other side of the same coin, the tequirement could have been supported as an economy measure in the light of other competing claims on the federal budget. As recently as 1959, the Eisenhower Administration opposed a relaxation of the requirement on the ground it would divert too much of the grant authorization from resiclential projects. ${ }^{101}$ There avas also the concern that the resulting broader scope of the program would create greater pressure for increases in the capital grant authorization at a time when the demands of foreign aid and defense were pressing. ${ }^{102}$

If it is assumed that some priority should be given to the removal of slums and to housing redevelopment, the question would still remain as to whether the predominantly residential requirement is an effective and equitable method of providing that priority. Is the best standard for this purpose the fact that at least fifty-one per cent of the area is residential either before or after redevelopment?

Obviously, many varying factors enter into a decision that a particular project has the greatest urgency or long-term value to the citizens of the urban area. There are the cost, the relative feasibility in terms of special problems of land acquisition or disposal, the extent and degree of physical deterioration or obsolescence of structures, the effect of the condition of the area on the health and welfare of its occupants or citizens of the community as a whole, and the obstacle which that area may present to improvement. of other parts of the community. The degree and extent of

${ }^{102}$ Hearings Before the Senate Comnittee on Banking and Carrency on the President's Message Disapproving S. 57, 86th Cong., 1st Sess. 106 (1959).

202 As a substitute to such relaxation, the Administration proposed a program of temporary and 10year refunding loans, without grants, for nonresidential redevelopment projects. In making this proposal in 1958, the Administration witnesses stated that use of capital grant funds was not warranted for coping with commercial and industrial blight. See Hearings Before the Housing Subcommittee of the House Committee on Banking and Currency on the Housing Act of 1958, 85th Cong., ad Sess. 28 (1958). See also Hearings Before the Housing Subcommittee of the Senate Conmittee on Banking and Currency on the Housing Aat of J958, 85th Cong., 2d Sess. 127 (1958). 
blight in the residential portion of a project is important,-as well as the ground area covered by such blight; and these must be considered in relation to the degree and extent of blight in the commercial or industrial portion of the project. In case of urban renewal projects involving rehabilitation, the problem is even more complex.

All of these factors and many more should be considered by a community in selecting a specific site as the one which most warrants its financial aid and federal expenditures, and each factor should be properly weighted. In general, the proportion of the area that is residential should be one of the heavily weighted factors. However, no fixed ratio of fifty-one per cent or any other percentage could afford the best standard for all cases, as it would give no consideration to other factors. We recognize that inequities can be shown under most'statutory priorities, because by their nature they are shortcuts to administrative decisions. However, in the case of the predominantly residential requirement, it seems to the writers that the degree of artificiality involved is too great to be justified in terms of administrative convenience.

Parenthetically, it may be of interest that no significant controversy over the predominantly residential requirement arose during the period immediately following the enactment of the 1949 Act. Instead, all of the fire at that time seems to have been directed toward the Agency's interpretation of the related provision in the Act authorizing a project of "open land necessary for sound community growth which is to be developed for predominantly residential uses."103 There the $i$ sue was whether an open land project involving no element of blight may be undertaken only if it provides housing as an adjunct to slum clearance projects in the community, as the Agency contended, or could be used to provide housing for other purposes such as "new towns" or satellite communities or public housing for any low-income families in the community. In defending its position, the Agency conceded that sound community development was a purpose of the act but contended that "the dog is slum clearance, and the tail is community development." The issue, while vigorously argued on both sides, was nevertheless somewhat academic in the absence of local pressure for specific federally-aided open land projects. However, it continued to be a subject of debate until Senator Douglas, in an address before the National Housing Conference on May 6, 1952, praised the Housing Agency for following legislative history and the intent of Congress instead of the recommendations of some of the prominent members of that organization. ${ }^{104}$

${ }^{203}$ See note 87 supra.

${ }^{102}$ 'The Act did not specify the more restrictive use of the open-land authority; that was promised in a letter from the Housing Agency requested and used on the Seriate floor by Senator Douglas during dcbate on S. 1070, 81st Cong., Ist Sess. (1949). See 95 Cong. Rec. 4876-77 (i949). It was contended by promineht counsel that there was no ambiguity in the law, and the Agency was therefore in error in going to the legislative history on the matter. This points up the distinction between the use of legislative history by a government agency administering discretionary authority and its use by a court or an administrative tribunal engaged in a judicial or quasi-judicial proceeding affecting the legal rights of parties who are reasonably entitled to rely on the plain meaning of a statute. To a government attorney, it seems quite unrealistic in the former case, to say the least, to expect an agency to ignore the clear intent of a vast majority of the Congress to limit the Agency's discretionary authority to a narrower scope than expressed in a statute. This footnote is not intended to imply that there were not also round 
The response of Congress to pressure for assistance to nonresidential projects (including several specific projects which were called to the attention of individual members of Congress by their constituents) is reflected in the authorized exceptions to the predominantly residential requirement. A major exception was enacted in the Housing Act of 1954 , which permitted ten per cent of the authorized federal capital grant funds to be used for nonresidential projects. ${ }^{105}$ However, a project was eligible only if it contained a substantial number of slum or deteriorating dwellings or other substandard living accommodations, the elimination of which would tend to promote the public health, safety, and welfare and only if the area "is not appropriate" for redevelopment for predominantly residential uses. ${ }^{108}$ The general exception has grown to twenty per cent. The Housing Act of r959 not only changed the ten per cent limitation to twenty per cent, but also removed the requirement that the project area have a substantial number of substandard dwellings. ${ }^{107}$ Thus Congress has departed from the principle that each urban redevelopment project should involve the removal of substandard housing or the construction of

policy reasons for not exercising the suggested broader authority. Not the least of these was the absence of court decisions establishing the validity of open-land projects in any state; constitutional difficulties were anticipated in underaking open-land projects, even though necessary as an adjunct to slum clearance operations. Subsequently, the validity of predominantly open-land projects where there is some element of blight has been upheld in three states. See the grounds for decision stated in Redevelopment Agency of City and County of San Francisco v. Hayes, 122 Cal. App.2d 777, 266 P.2d ro5 (1954), cert. denied sub nori. Van Hoff v. Redevelopment Agency, $34^{8}$ U.S. 897 (1954); People ex rel. Gutknecht $\checkmark$. City of Chicago, 4I. IIl. 600, 11 I N.E.2d 626 (1953); Oliver v. City of Clairton, 374 P2. 333, 98 A.2d 47 (x953); and Pcople ex rel. Adamowski r. Chicago Land Clcarance Commission, 14 Ill.2d 74, 150 N.E.2d 792 (I958).

${ }^{108} 68$ Stat. 626,42 U.S.C. 51460 (1958).

200 The exception came to be known as the "skid row" amendment because it tended to affect areas which had a scattering of substandard rooming houses or "flop" houses. The Housing Agency administratively determincd that the requirement that the area include 2 substantial number of dwellings or other living accommodations would be met if $20 \%$ of the ground area or floor area were devoted to residential uses seattered throughout the area. The Housing Act of 1954 continued the predominantly residential reguirement with respect to the cleared ares of a project, but did not extend it to other parts of the broader urban renewal area authorized in that act. The requirement was made applicable to the entire urban renewal area (instead of just the elearance area) by 302 of the Housing Act of 1956 (70 Stat. 1097). This had the cffect of relaxing the requirement where the rehabilitation portion of the area was residential. See also a minor exception for certain nonresidential projects, involving federal loans but nest grants, in the last paragraph of $\$ 110(c)$ of the Housing Act of 1949, as amended, 70 Stat. 1097,42 U.S.C. $\$ 1460$ (1958). This minor exception was added by $\$ 106(c)$ of the Housing Amendments of 1955, 69 Stat. 635, 637, 42 U.S.C. 51460 (1958).

${ }_{201} 5413$ of the Housing Act of 1959 (73 Stat. 675, 42 U.S.C.A. 51460 (Supp. 1959)) changed the relevant language of $\$ 110(c)$ of the Housing Act of 1949 to read as follows: "Financial assistance shall not be extended under this title with respect to any urban renewal are2 which is not predominantly residential in character and which, under the urban renewal plan therefor, is not to be redeveloped for predominantly residential uses: Prozided, That, if the governing body of the local public agency determines that the rederelopment of such an area for predominantly non-residential uses is necessary for the proper development of the community, the Administrator may extend financial assistance under this title for such a project: Provided further, That the aggregate amount of capital grants contracted to be made pursuant to this title with reppect to such projects after the date of the enactment of the Housing Act of 1959 shall not cxced 20 per centum of the aggregate amount of grants authorized by this tille to be contracted for after such date"

This language deleted a requirement that a predominantly residential project be "clearly" predominantly residential. 
housing in order to justify the federal aid. However, there has been no departure by Congress from the premise that the program as a whole should be housingoriented and that restrictions should be included in the federal law for this purpose. In recommending the 1959 amendment, the report of the Senate Committee on Banking and Currency stated: ${ }^{108}$

The committee agrees that the basic objective of the program is to eliminate slums and blighted homes but also recognizes that no community can survive without an orderly plan for renewing its commercial and industrial areas. Urban renewal in its broadest sense would renew the entire living environment of the community including its commercial areas where families must shop and its industrial areas where families must work, as well as its residential areas where families live. It is appropriate, therefore, that a reasonable percentage of Federal assistance should be used to assist a community in renewing nonresidential as well as residential areas.

When a statutory limitation is under basic attack, there is frequently, if not generally, an accommodation which avoids the complete removal of the limitation. It may be retained in modified form because of the belief that it has not yet outlived its usefulness or because of the legislature's reluctance to admit that a change in principle is involved or perhaps because of the legislature's instinctive reluctance to surrender a control. Sometimes general exceptions are provided, such as the ten per cent or twenty per cent exception to the predominantly residential requirement, and at other times exceptions are made for specific narrow purposes. ${ }^{108}$ A number of the latter type of exceptions to the predominantly residential requirement have been enacted and others have been proposed. Taken together, they could represent a very substantial increase in the authorized volume of nonresidential projects and a substantial erosion of the basic limitation.

In 1956 , the predominantly residential requirement was waived, along with other prescribed limitations, for urban areas which are in need of redevelopment or rehabilitation as the result of any catastrophe which the President finds, under other legislation, to be a major disaster. ${ }^{120}$ In 1959 , a more substantial waiver was enacted with respect to urban renewal projects which the local governing body finds will be of certain benefit to a college or university in or near the project area. ${ }^{111}$ This 1959 exception would be extended to hospitals by bills pending in the Eighty-sixth Congress when it adjourned, one of which was passed by the Senate, ${ }^{112}$ and the other

\footnotetext{
${ }^{200}$ Senate Comm. on Bariking and Currency, Hosssing Act of 1959, S. REP. No. 4x, 86th Cong., Ist Sess. 27 (1959).

${ }^{109}$ Very frequently 2 proliferation of such statutory modifications, including some which are designed to take care of single eases, resultes in extremely complex legislation. This has happened in the field of urban renewal legislation. It is interesting that groups which have sponsored complicating changes, one by one, are often among those who complain vigorously about the sesulting over-all complexity.

${ }^{210} 5$ IIr of the Housing Act of 1949, as added by 507 of the Housing Act of 1956, 70 Stat. 110x, 42 U.S.C. 1462 (1958).

${ }^{111} 5112$-of the Housing Act of 1949, as added by $\{418$ of the Housing Act of 1959,73 Stat. 677, 42 U.S.C.A. 51463 (Supp. 1959).

${ }^{112}$ S. 3670, 86th Cong., ad Sess., passed by the Senate, June $26,1960$.
} 
of which was reported by the House Committee on Banking and Currency. ${ }^{113}$ A number of recent bills, including some sponsored by the Eisenhower Administration and others sponsored by the Democratic congressional leadership, would also waive the predominantly residential requirement with respect to certain urban redevelopment projects in industrially depressed areas. ${ }^{114}$ These further exceptions or waivers will undoubtedly be considered in the Eighty-seventh Congress.

If the trend to relax the predominantly residential requirement is continued, a point will soon be reached where it has no real limiting effect. Indeed, in the case of cities where the extent of industrial and commercial blight does not constitute a disproportionate share of urban blight, a question may be raised as to whether this point has already not been reached. A 1955 analysis $^{11 . \pi}$ of fifty-three municipalities shows the land use of developed areas as follows:

Residential $\ldots \ldots \ldots \ldots \ldots \ldots$ About $73 \%$
Commercial $\ldots \ldots \ldots \ldots \ldots$ About $6 \%$
Industrial \& railroads........... About $21 \%$

If about seventy-three per cent of municipal areas are residential, the twenty per cent exception, along with special purpose exceptions, should often be adequate to permit nonresidential urban renewal projects to be undertaken in about the same proportion to predominantly residential projects as nonresidential land use in the locality bears to residential land use. An additional factor which tends to make this true is that a project is charged against the exceptions only if it involves a predominantly nonresidential area to be developed for predominantly nonresidential uses. Thus, the volume of projects involving predominantly commercial or industrial areas can equal the volume permitted under the twenty per cent exception (and additional special exceptions) plus the volume of these projects which are developed for predominantly residential uses.

Although the form of future legislation on this particular subject cannot be predicted, the writers do venture to predict with some assurance that it will continue to be an active issue, with changes moving in the direction of greater freedom to undertake nonresidential projects. There is still a strong belief among many in Congress that the principal objective of the urban renewal program is the removal of slums and the improvement of housing, as distinguished from general city betterment. Others will continue to regard the predominantly residential requirement as a desirable economy measure, preventing added claims against federal grant funds. On the other side are the municipalities and local officials, ably represented in Congress

${ }^{128}$ H.R. 12603, 86th Cong., 2d Sess. (1960); House Comm. on Banking and Currency, Houssing Aat of 1960, H.R. REP. No. 1924,86 th Cong., 2 d Sess. (1960).

${ }^{124}$ One such bill, S. 722, 86th Congress, 2d Sess. (1960), was vetoed by President Eisenhower on grounds unrelated to this provision. See also S. 1433,86 th Cong., $2 \mathrm{~d}$ Sess. (1960), ari Administrationsponsored bill, and S. 3569, and H.R. 12286, both 86th Cong., 2d Sess. (1960), compromise bills proposed on behalf of the Administration.

${ }^{215}$ See Harland Bartholosaew, Land Uses in American Cities 121 (1955). The analysis coveted cities of varying sizes. Developed areas considered fere do not include streets, parks and playgrounds, and public and semipublic property. 
and before its committees, who want more discretion in planning and deciding the type of projects to be undertaken. An added force which seems to be tipping the balance in their favor is the position of business interests which normally tend to support restrictions on federal expenditures, but are increasingly in favor of reconstructing blighted business and industrial properties. Foremost among these are department store owners and mortgage and other lenders concerned about large outstanding investments in downtown retail properties now suffering competition from surburban shopping centers. Redevelopment to provide downtown commercial centers with parking space and attractive surroundings is a business necessity to them and a source of increased tax revenue to the city.

\section{B. Federal-Local Sharing of Costs}

The basic statutory formula ${ }^{216}$ for sharing the costs of the urban renewal program as between the federal government and local governments has been under attack from opposite directions. Skipping over problems and statutory changes relating to technical methods of calculating the federal and the local share of program costs, it is the writers' intention to comment on attempts to change materially the relative size of the two shares.

In 1958 , the Housing and Home Finance Administrator, as spokesman for the Eisenhower Administration, recommended the enactment of legislation ${ }^{117}$ to reduce the federal share of net project costs to sixty per cent one year later, fifty-five per cent two years later, and fifty per cent three years later, with a resulting final increase in the local share to a matching fifty per cent. The change through gradual stages was intended to give localities, and possibly states, time to gear themselves to assuming the permanent larger burden. The Administrator stated:118

The reasons for this recommendation are based, of course, upon considerations of the general fiscal policy of the Government and the need for greater participation on the part of States and localities in bearing the financial burden of undertakings having primarily local as well as national benefit. If essential programs such as urban renewval, which require large amounts of funds, are to be continued at their present levels, States and communities should bear a greater share of the financial burden. We do not know the total ultimate cost of eliminating all of the slums and blight in our country, but we can agree it is a staggering sum and that all of the Federal funds that could be made available would accomplish only a part of the job in the immediate future. Local expenditures should be of equal importance to the amount of work completed.

Unlike many other Federal-aid programs, urban-renewal projects result in direct financial benefits to communitics, in addition to the immediate objective of the program In addition to slum elimination and all of its benefits, cities receive an increased tax base

\footnotetext{
120 Sce $\$ 5103(a), 104,106(f)$, and $x r o(d),(e),(f)$ of the Housing Act of 1949, as amended, 71 Stat. 299, 300, 301, 42 U.S.C. $551453(2), 1454,1456(f), 1_{4} 60$ (d), (c), (f) (1958).

227302 of S. 3399, 85th Cong., 2d Sess., Administration-sponsored bill introduced on March 4, 1958, by Senator Capehart of Indiana by request. A similar proposal was contained in 5304 of S. 612, 86th Cong., Ist Sess., Administration-sponsored bill introduced on January 21, 1959 by Senator Bennett of Utah for Senator Capehart.

${ }^{210}$ Hearings Before the Subcommittee on Housing of the Senate Committee on Banking and Currency
} 
of great and immediate financial value. In the long run, many cities mây receive over a period of years sufficient increased taxes as a result of rederclopment and improvements in urban renewal areas to pay all of their local grants-in-aids-not only their cash contributions but their grants in the form of improvements and facilities. It is because of these facts, as well as other advantages of urban renewal, that so many cities are enthusiastically proceeding with their projects. Under the bill, communities would eventually pay onesixth more of the net project cost than they pay with respect to projects now being undertaken. In view of the extent of present activities, it seems wholly unrealistic to assume that this modest increase would restrict our program.

During the course of the ensuing controversy; the Eisenhower Administration made it clear that its proposal was primarily motivated by its judgment concerhing relative priorities of competing claims, including national defense and foreign aid, on a federal budget which it hoped to keep in balance. The Administration spokesmen argued that whatever upper limit might be placed on federal funds available for urban renewal, a larger total program could be supported if the local share of the cost were increased. This argument for making a given amount of federal funds stretch further was premised on the ability of localities gradually to assume the increased burden without undue hardship. The present level of activities was offered by the Administration as an indication that it was not unrealistic to expect that the cities could contribute even more. The Administration also felt that the states should participate in the program more than they had. Indeed, the proposal for reducing the federal share of urban renewal costs was part of an abortive Administration drive for returning to the states and localities greater responsibility for socially motivated programs generally.

In the meantime, local urban renewal officials, mayors, and other spokesmen for urban interests had been contending that even the present $2 / 3-1 / 3$ formula placed undue hardship on the localities. From time to time, they proposed that the federal share of net project cost be increased to scventy-five or eighty per cent or even ninety per cent. ${ }^{118}$ The President of the National Association of Housing and Redevelopment Officials made the following statement in opposition to any reduction in the federal two-thirds share and in support of increasing it to eighty per cent: ${ }^{120}$

on the Housing Act of 1958, 85th Cong., 2d Sess. 118-19 (1958). See also, the testimony by the Urban Renewal Commissioner, id. at 122-24, and in Hearings Before the Subcommittee on Hotsing of the Sente Committee on Banking and Cturrency on the Housing ACe of 1959. 86th Cong., Ist Sess, 119-20 (1959).

210 These proposals for increasing the federal share should not be confused with a change which was enacted in the Housing Act of 1957. \$302 of that act, 71 Stat. 299, 42 U.S.C. 1453 (1958), provided for the establishment of an alternative basis for calculating the federal capital grant. It permits a community to elect to receive either a two-thirds federal grant or a three-fourths federal grant with the higher percentage grant being based on gross project costs which do not include certain expenses of planning, surveys, legal services, and administrative overhead. The excluded costs are borne entirely by the local community. In effect, under the alternative formula, the federal government pays a higher percentage of a reduced project cost. In proposing the formula, the Housing Agency expressed the expectation that the federal share of the total costs would prove to be about the same under either formula, and stated that the purpose of the altcrnative formula is to make it possible to eliminate review and discussion at the federal level of survey, planning, and administrative costs.

${ }^{130}$ Hearings Before the Subcommittee on Housing of the Senate Commitzee on Banking and Cur. 
I need only recite some of the linsncial problems with which American citics are faced today-declining tax bases, limited tax resources, substantial increases in the costs of providing essential municipal services, the necessity for providing new types of municipal services, and the demands of municipal growth-to explode the myth that our cities, or our States for that matter, can, or even shuuld, absorb a greater proportionate part of the cost of urban renewal.

The Federal-local-sharing formula is the price tag which the Federal Government places on the local participation in urban renewal. By raising the price, a substantial number of communities-many of those who are most in need of an aggressive urban renewal program-will either be priced out of the program completely or unable to buy as much of it as they need.

The United States Conference of Mayors has also recommended that the federal share be increased to eighty per cent. ${ }^{1: 1}$ The Mayors of Boston, Milwaukee, and Gadsden, however, have suggested a ninety per cent federal contribution, ${ }^{1: 2}$ and the Mayor of New York, when asked what he thought about the suggestion, gave the following answer: "I mentioned that one of the recommendations at the Conference of Mayors was that the Federal contribution in redevelopment be increased from $66-2 / 3$ to eighty per cent. If anyone would want to sponsor going to ninety per cent, I am sure the cities would appreciate that too."123

Although he was addressing himself to a different though related issue, the Mayor of Philadelphia in $195^{8}$ argued as follows against asking the states to take over some of the responsibility for the urban renewal program: ${ }^{124}$

It takes no great political knowledge to realize that this could only result in a sharp reduction in the program-because of the rural domination of State legislatures as well as the lack of State resources.

Thirty-five years ago, 75 percent of the taxes went directly to the cities and the States. Today, the Federal Government takes 75 percent and the cities and States get only 25 percent. True, the Federal Government's responsibilities have grown in those years. But so have those of the cities and States.

Particularly is this true of the cities, with their vast influxes of population. We in Philadelphia have, in the past 5 years, increased our taxes by 35 percent, largely to meet this very problem....

The third of a billion dollars allocated this year for urban renewal is less than onehalf of I percent of our national budget. It would not even be enough to pay for a single aircraft carrier.

On a later occasion, the Mayor argued that the cities have been receiving a steady influx of lower-income groups, including disadvantaged nonwhite groups, with

rency on the Housing Act of 1959, 86th Cong, ist Sess. 572 (1959). See also, id. at 582, and, for earlier recommendations by the Association, see Hearings Before the Subcommitfee on Housing of the Honse Committee on Banking and Currency on Slum Clearance and Related Housing Prollems, 8sth Cong., 2d Sess. 90, 93 (1958).

131 Hearings Before the Subcommittee on Housing of the House Committee on Banking and Currency on Slum Clearance and Related Housing Problems, 85th Cong., 2d Sess. 188 (1958).

192 Id. at 190, 192, 243.

iss Id. at 254 ; sce also id. at 255.56 .

res Id. at 214 . 
greater social needs and lower tax-paying ability, while higher-income families have tended to move across city lines to the suburbs. ${ }^{125}$ Others have often pointed out that states and cities must avoid increasing their taxes too sharply in relation to other states and cities in order to avoid driving industry across their borders.

Finally, an argument has been made that the federal tax structure is more pro ductive and more equitable than state and local tax structures can possibly become in the foreseeable future, so that it is desirable to finance nationally-important pro grams largely with federal tax revenues. Senator Clark of Pennsylvania, in a lecture delivered at George Washington University on March 28 , $1960,{ }^{126}$ stated that local budgets are inadequate partly because of an unwillingness to tax but more importantly because of a lack of real resources. He stated that federal revenues have risen by seventy-four per cent since 1946 , but state and local revenues have more than tripled; that state and local tax rates have risen steadily, while federal taxpayers have enjoyed tax reductions; that federal indebtedness has risen five per cent since 1946, while state and local debt has risen to 309 per cent; and finally that state and local tax burdens fall far more heavily on poor and moderate-income families than do federal tax burdens. Thus, Senator Clark argued that most local tax dollars are still collected from the real property tax, although the ownership of real estate has long ceased to be a good indication of relative wealth. That is, the owner of a heavily mortgaged home may be taxed on hardly any equity at all, whereas a man who is better off, with wealth largely in a safety deposit box, escapes local taxation on these assets, but is reached by federal taxation. On the further grounds that "over half of all State tax revenue now comes from sales and excise taxes," Senator Clark concluded that both "State and local taxes fall far more heavily upon the average- and lower-income families," whereas "the brunt of Federal taxation falls upon the corporations and the upper-income families."

It is apparent from the foregoing and from a reading of all the congressional discussions over a period of several years on the issue of the federal-local share of urban renewal costs that the arguments on both sides tend to be quite general and would just as logically support raising or lowering a fifty-five or seventy-five per cent federal grant as they would support raising or lowering a $66-2 / 3$ per cent federal grant. If objective studies have been made which would truly sharpen this issue quantitatively, they have, so far as we know, not been presented at any of the congressional hearings. Instead; both sides have presented their positions primarily in terms of what seems to them "equitable" and of the problems with which they are each faced in obtaining revenues needed for competing purposes. Under such circumstances, the congressional decision-making process necessarily tends to rest more

${ }^{196}$ Hearings Before the Subcommittee on Housing of the Senate Committee on Banking and Currency on Housing Legislation of 1960, 86th Cong., 2d Sess-392.(1960).

${ }_{193}$ Toward National Federalism, 106 Conc. Rec. A3007, A3008. (April-5, 1960). (reprinted at: the request of Representative Bowles of Connecticut): 
heavily than is usual on visceral reactions. Indeed, this same tendency may be detected in the testimony by the Mayor of New York, quated above, in which he recommended an eighty per cent federal grant, but thought that the cities would appreciate going to ninety per cent if anyone would want to sponsor the higher level. Similarly, in 1960 the Mayor of Philadelphia, testifying as President of the United States Conference of Mayors, stated that the recommendation of the Conference was for a four to one federal-local grant ratio, and then added: "I personally think that 3 to $I$ would be a very fair figure. I mean, that is purely my personal position on it." 128

It is interesting to note that the $2 / 3-1 / 3$ cost sharing formula was originally recommended by the Executive Branch without any pretense that a different ratio would be unreasonable. Recognizing that large sums of money would be involved which it would be difficult for cities to raise, and allowing for greater local resistance to newer forms of municipal expenditures, it was thought desirable to exceed substantially the fifty per cent matching grant formula which is customary in almost all federal aid programs, while at the same time requiring the locality to have a truly substantial stake in a program which would benefit it both socially and financially. The present ratio seemed about right for this two-fold objective. Ten years later, it still seemed about right to Mr. William Zeckendorf, Sr., the prominent redeveloper. During a congressional hearing in January 1958 , the following exchange occurred between him and Representative McDonough of California: ${ }^{128}$

Mr. McDONOUGH. What percentage should it be?

Mr. ZECKENDORF. Well, I think if it got to be less than a third, it would be too much of a free ride, and I think there should be enough of a challenge to local pride to make sure they know they have got to pay something in, however substantial it may appear to them to be, or insubstantial it may appear to you to be.

I think this one-third is about as close to being good as you can get, and I think if you change it, and made it, let's say, 50-50, that it might have an end result that would be antithetical to urban renewal on a national scale.

The Eisenhower Administration has reasoned that a substantial local investment in the urban renewal program assures greater interest on the part of the local electorate and closer supervision by elected local officials, and that this in turn makes for more efficient and more economical operations. It is also often pointed out that federal supervision will inevitably tend to increase to a level which the localities will find onerous if ever the local share of the cost is reduced to a point where it represents no substantial burden on the community. This line of argument is almost always presented in the context of the supervision which is necessary to avoid wasteful administration and inefficient operations. It brings to mind possible losses in. administrative and overhead costs which may in a few years run to hundreds of

${ }^{127}$ Hearings, stupre note 125 .

128 Hearings Before the Subcomnsittee on Housing of the House Committec on Banking and Currency on Slum Clearance and Related Housing Problenss, 85th Cong., 2d Sess. $33^{6}$ (1958). 
thousands of dollars in a single fair-sized city and to possible losses from unwise land assembly or land sale methods which may run to a few millions of dollars. However, it may reasonably be contended that even more is at stake if ever the local financial burden ceases to be substantial. To explain this, it is necessary to identify a current which flows just below the surface of public discussion, and which may be turned against the program.

Underlying most major renewal plans are basic judgments which are not really capable of being based on objective grounds. Even assuming that primary responsibility for the local plans is assigned to mature and highly competent professional planners; and that the planners have been able to recognize all the major problems which are within the special competence of civil engineers, architects, transportation specialists, constitutional and municipal lawyers, land developers, buildu, s, mortgage lenders, real estate dealers, land appraisers, sociologists, social workers, and civic leaders acquainted with local and neighborhood groups affected by the project; and even assuming that each of these specialists and all of the local elected and appointed officials are friendly to the program, competent, and inclined to work harmoniously in ascertaining, and reasoning from, all relevant information; and that none of the directly affected groups is hostile to the urban renewal process-there could still be a major missing ingredient for determining the basic direction of the local program. That missing ingredient is the sum of the purely subjective value judgments which must be made before a community can determine how some of our most valuable national economic resources should be allocated.

Across the nation, decisions must be made which will, over the long run, affect economic resources worth not millions, but billions of dollars. For example, city by city, questions will arise as to the price which the public should be willing to pay for low building densities and esthetically pleasing public buildings and vistas. These judgments do not turn on objectively verifiable data; they tend to defy our collective wisdom; and yet they must be made. They are too important to be made by professional planners alone, as the planners are often quick to admit. Clearly these value judgments would generally not be made in the same way by conscientious and economy-minded members of a congressional or municipal appropriations committee as they would be made by professional planners desiring, commendably, to emulate Marcus Agrippa, L'Enfant, and Haussmann. Unless there is a flexible means for resolving this type of issue, it may well, at some future time, give rise to inflexible restrictions in federal legislation.

The practical way of democratically reaching an accommodation on such differences locally is to see to it that the judgments involved will be that of the community as a whole, and that can best be done by placing a substantial financial burden on the community. More important, judgments which determine the allocation of vast national resources should not be made even by the entire local community if it is not first required to face up to hard decisions as to whether desirable 
civic amenities are so desirable that the community itself is willing to sacrifice something of value for them. Thus, attaching some element of pain to the local urban renewal burden is not only justified by the local benefits which will follow, but also as the price which the locality should pay for the freedom to make basic value judgments affecting its own future. The policies of federal agencies are subject to wide swings of the pendulum as one point of view or another gains dominance in Congress, in the White House, and in the national electorate, and the best assurance that the most basic policies in local urban renewal programs will continue to be decided locally is to avoid shifting too much of the program's cost to the federal government. More specifically, there may be avoided on some future swing of the pendulum the enactment of unduly inflexible federal requirements relating to such matters as competitive bidding and priorities to site occupants, as well as oncrous control over the nature of the program through prior congressional approval of appropriations and through possible congressional pressures against more novel or more expensive projects.

In the meantime, the recent direction of the congressional pendulum indicates a real possibility that the local share of urban renewal costs will actually be reduced too far. To understand why this is so we must consider, along with the pressures to reduce the statutory one-third local share to one-fourth or one-fifth or even onetenth, other less obvious, but important, tendencies to lighten that share. These relate to the so-called "noncash grants-in-aid" which a locality may provide to assist its urban renewal projects and to certain project expenditures such as those for streets.

The noncash grants may take the form of schools, parks, playgrounds, or other public facilities, either on or off the project site, which are necessary for carrying out the project. If the public facility is of direct benefit to other areas as well as to the urban renewal project area, only a prorated portion of its cost is counted as a local grant. The eligible cost enters into the calculation of the gross project cost as well as of the local grant-in-aid so that the federal two-thirds and the local onethird shares are each calculated against a net project cost which reflects expenditures made for the public facilities. ${ }^{129}$

The Taft Subcommittee Report of August I, I945, had recommended that "expenditures on public buildings made necessary by the project" be recognized as local contributions "only to the extent that these expenditures exceed what the munici-

\footnotetext{
${ }^{220}$ Informal proposals made in Congress that a public facility be counted as a local grant-in-aid but not as part of gross project cost were not strongly pressed because, in aldition to placing a financial burden on the community, the exclusion from gross project cost would, as a practical matter, upset the financing arrangement of the program. Members of Congress who were not persuaded by the first reason were persuaded by the second. Thus, in the example in Part III of a project having a gross cost of $\$$ ro million, if the $\$ \mathbf{1}$ million figure for provision of public facilities were excluded from the total in " $A$ " (Gross project cost), to which the two-thirds federal and one-third local grants are applied, and if corresponding changes were made throughout the example, the total under " $E$ " which is available for repaying the borrowings referred to in " $\Lambda$ " would alway's, as a matter of arithmetic, be inadequate so long as the city continued to receive grant-in-aid credit for the public facilities.
} 
pality would spend for the same purpose if there were no project."130 The literal application of this hypothetical test was rejected as not being administratively practical. That is, no federal official should be required to guess what a municipality might have done under other circumstances. For example, from the very beginning of the urban redevelopment program under the 1949 Act, if an old school, no matter how dilapidated, were replaced by a new one which drew all of its pupils from the urban redevelopment project area, the entire cost of the new school would be credited as a local noncash grant-in-aid, even though it was reasonably certain that the old school would have had to be replaced before too long whether or not the surrounding slum area was cleared. Thus, it should be recognized that from the very beginning of the program, some local expenditures which do not really represent an additional burden on the local community caused by the urban renewal program count as local urban renewal grants and also enter into gross project cost, thereby affecting the size of the federal grant. This fact is not cited with any intention of criticizing the policy, but it is relevant in evaluating the weight of the burden which the program places on the locality.

Similarly, expenditures for street improvements within an urban renewal area may be eligible as a direct project cost, even though there is a possibility that the improvements would have become necessary before too long anyway. This factor has become more significant since the 1954 amendments which extended the program to rehabilitation and conservation activities. Projects involving such activities generally cover larger areas than projects involving only clearance. Thus, there may be more streets to be improved, while at the same time there is less need for large outlays involved in land acquisition and the clearance of structures. Conservation and rehabilitation projects therefore tend to involve relatively greater use of federal funds for activities which have been traditionally carried out entirely.at municipal expense.

In the early days of the program a problem arose under the requirement that a local grant-in-aid shall be "in connection with" a project "on which a contract for capital grant has been made" The requirement is reasonable but its application not always casy. Clearly, a locality ought not to be permitted to count the cost of a school if it had begun to lay the foundation before it even contemplated that there would ever be an urban redevelopment project in the vicinity. Obviously, too, the result would be unfair if a city were penalized because, before cold weather had set in, it had begun construction on a school needed for a redevelopment project, withour waiting until all the formalities involved in entering into a federal aid contract had been completed. Basically, the problem involved is one of finding an administratively workable test for determining the intended connection between the school or other public facility and the future urban redevelopment project. This problem was first met by having the local public agency obtain a written "prior approval" from the

${ }^{300}$ Taft Stbcommittee Report ig (Aug. x, T945). 
federal government which permitted the public facility to be started, without loss of local grant credit, before the federal aid contract was signed. In view of the long period of planning which may be involved in a project, the prior approval could be given several years before the federal urban redevelopment loan and grant contract. Although this particular device (and similar later devices based on identifying a project in a contract for planning advances) appeared to the Executive Branch to provide a reasonable way to meet the demand for flexibility and the need for establishing a "good faith" connection between the public facility and the future urban redevelopment project, many localities and Congress thought otherwise.

Section 413 of S. 57 , Eighty-sixth Congress, which was vetoed by the President on July 7 , 1959, would have provided that a public facility otherwise eligible as a local grant-in-aid shall not be deemed to be ineligible because of the absence of a federal "prior approval" provided that the construetion of the facility was started not more than five years prior to the Housing Administrator's authorization of 2 contract for loan or capital grant for the urban renewal project. Even the failure to notify the Administrator that a public facility had been started could not, under the section, be used as a basis for declaring the facility ineligible as a local grant-in-aid. This provision would not have removed the substantive requirement that the eligible public facility be necessary to serve an urban renewal project, but it would have eliminated a workable method for determining that the municipality had originally provided the facility in order to serve a future renewal project rather than as a routine municipal improvement. The provision was criticized by the President in his veto message ${ }^{131}$ as having the effect of reducing the local contribution.

A similar provision, but with the five-year period reduced to three, was later enacted in section $4 \mathrm{I} 4$ of the Housing Act of 1959 . The Senate Committee report ${ }^{132}$ stated that "it is the committee's intention that local public works be credited under this provision only if the projects are clearly a part of, and contributory to, the urban renewal project." The reduction of the period from five years to three years and the statement in the Committee report removed some of the danger, which was inherent in the earlier provision, that substantial urban renewal funds would be diverted into a federal program of aid for municipal public facilities. However, it still will result in credit being given for schools and other local facilities which were provided with no intention at the time to have them serve a future renewal project. While this provision represents a material chipping away of the local share of urban renewal costs, it will perhaps not cause as large a reduction in that share as another type of change which was made in the 1959 Act and which may be extended further.

In order to encourage urban renewal activities near the many colleges and uni-

${ }^{122}$ Message from the President of the United States, Housing Act of 1959-Vero Message, S. Dac. No. 34, 86th Cong., Ist Sess. (1959).

${ }_{134}$ Senate Comm. on Banking and Cursency, Housing Act of 1959, S. REP. 715, 86th Cong., 1st Sess. 6 (1959). (Emphasis supplied by the Committec.) 
versities which have been affected by blight in neighboring areas, section $4^{18}$ of the 1959 Act added a new section 112 to the 1949 Act. $^{132 a}$ A major effect of this new section is to permit a local urban renewal agency to obtain noncash grant-in-aid credit for expenditures made by a college or university for acquiring land and buildings within or in the immediate vicinity of an urban renewal project area. The buildings may be acquired by the educational institution with the intention of rehabilitating or clearing them, and the clearance expenditures made by the educational institution. would add to the local public agency's grant-in-aid credit. Expenditures made by the educational institution as long as five years prior to the authorization of an urban renewal loan and grant contract would be eligible. Also, unlike acquisition of land and buildings by the local public agency itself, there will be no disposition proceeds to) offset the acquisition cost which enters into the noncash credit.

Where an educational institution has, within a five-year period, engaged in an extensive expansion program, the credit which the local public agency would receive could be very substantial indeed. Yet all of the expenditures would be made by the college or university and not by the city. The credit might well be large enough to provide the entire local grant-in-aid required for the later urban renewal project near the educational institution, and there may be enough left over to provide the local grant-in-aid required for several other local urban renewal projects having nothing to do with the college or university. Thus, the local public agency could retroactively receive a large credit which substantially shifts the financial burden of urban renewal activities in that locality as between the federal and local government.

It is relevant to ask why such a departure from the federal-local cost-sharing formula should be available in order to give colleges and universities additional urban renewal benefits. As no urban renewal funds are furnished to the institution, the benefits consist of advantages flowing from the improvement of the neighboring area by a federally-aided urbin renewal project and the opportunity to acquire in the vicinity additional land needed by the institution. Colleges and universities have an urgent need for expansion in the next few years, and the certainty of urban renewal in an area may be of considerable assistance to them in securing donors' funds required to carry out their building programs. The grant-in-aid credit would furnish a very strong incentive for a local public agency to undertake a nearby urban renewal project which would furnish these benefits to the institution, or to grant a higher priority than would otherwise be given to such a project over other urban renewal projects in the community.

Howcver, it appears to the writers that urban renewal activities in the neighborhood of colleges and universities would generally be so commendable a means of accomplishing the two-fold purpose of furthering urban renewal and higher education in the locality that no special inducement should be held out to the local public agency to do what it ought to be doing anyway. Conversely, if the possibility of obtaining a large grant-in-aid credit at no direct cost to itself should induce a local ${ }^{213 m} 73$ Stat. 677,42 U.S.C. $5 \times 463$ (Supp. 1959). 
public agency to plan an urban renewal project in the wrong place or at the wrong time, the federal treasury will have been called upon to underwrite a distortion of a federal program. It should be borne in mind that, as the responsibility for initiating urban renewal projects is solely that of the locality, the federal government is not in a practical position to reject an eligible project which has been presented to it for approval merely because other projects might more appropriately have been given a priority by the locality.

In any case, whatever the merits or faults of the amendment may be, it must be listed among the changes which tend to reduce the local share of the cost of urban renewal activities. Furthermore, as was predicted by some opponents, this change is being urged as a precedent for further similar changes in the law. Section 706 of S. 3670 , Eighty-sixth Congress (Housing Bill of 1960), as passed by the Senate on June 16 , 1960, and section 704 of H.R. 12603 (Housing i3ill of 1960), as reported by the House Committee on Banking and Currency on June 20, 1960, would extend these provisions to hospitals. Although no further action was taken in the Eightysixth Congress on legislation providing this extension, it will undoubtedly be considered in the Eighty-seventh Congress. It may be noted that universities often have extensive grounds and that many persons attached to a university live within its vicinity. Extensive grounds tend to make for a practical base from which to fight surrounding blight and the needs of students and faculty living on or near the grounds provide an additional motive for attacking surrounding blight. While similar considerations may reasonably be urged for hospitals, their force is greatly diminished by a major difference in degree. Thus, if hospitals are added to the 1959 provision, there will be little basis for rejecting the claims of a long list of other public institutions, thereby further reducing the local share of urban renewal costs.

Another feature of the act which departs from the $2 / 3-1 / 3$ cost-sharing formula is the provision under which relocation payments to families and business concerns displaced by urban renewal activities are paid entirely by the federal government. ${ }^{133}$ This departure, however, did not have its origin in pressures from municipalities to reduce their share of the cost. Instead, when legislation was introduced to authorize relocation payments under the regular cost-sharing formula, the Housing Agency pointed out that many localities would be unable to make these payments unless changes were made in state constitutions and statutes. Accordingly, the Agency suggested that if the relocation payments were to be provided for at all, they should be paid entirely out of federal funds. ${ }^{13 i}$ However, the Eisenhower Administration recently recommended that removal of the upper limits on such payments (now $\$ 200$ for families and $\$_{3}, 000$ for business concerns) should be conditioned on the state or

\footnotetext{
${ }^{292} \$ 106(f)$ of the Housing Act of 1949 , as amended, 71 Stat. 300,42 U.S.C. $51456(f)$ (1958).

126 possibly because the rationale for this $100 \%$ federal contribution with respect to relocation payments was lost sight of, legistation has recently been proposed providing that the salaries of lncal public employees engaged in helping site occupants to relocate themselves should also be paid entirely out of federal funds, thereby treating these salary expenditures differently from all other overhead costs of the program. See $\$ 80$ (c) of H.R. 12603, 86th Cong., as reported June 20, 1960 .
} 
locality assuming the responsibility for paying the one-third local share, even though this makes it necessary to amend state constitutions or statutes. ${ }^{135}$

Additional light on the entire question of the burden on the localities which is represented by the local one-third share of the cost is revealed by an unpublished study which the Urban Renewal Administration made early in 1959. It cstimated that up to December 31 , 1958, local grants-in-aid averaged about thirty-six per cent, rather than $33^{-1 / 3}$ per cent of net project costs, it being impossible exactly to gear the cost of grants-in-aid to future net project costs. This thirty-six per cent was estimated to be made up of cash grants averaging about fourteen per cent of net project costs, land donations averaging about two per cent, demolition averaging about 0.3 per cent, site improvements averaging a little under six per cent, and supporting public facilities averaging a little under fourteen per cent.

Undoubtedly, the tendency to cut down on the local share of urban renewal costs prompted a reference in the President's 1959 veto message on S. 57, Eighty-sixth Congress, to the fact that the local cash contributions have averaged only about fourteen per cent of net project cost. This reference brought quick replies pointing out that total local grants-in-aid were actually greater than one-third and that noncash grants-in-aid, as well as cash grants, represent real contributions to a renewal project. Both the statement and the reply are correct, but neither is addressed to the real policy issue which is raised by the entire trend to reduce the federal share of the cost. If we should couple with the past developments future reductions in the one-third share to as little as one-fourth or one-fifth, a truly substantial shift will have been made in the relative weight of the federal and local shares. The Mayor of Milwaukee has recommended "that the financing formula be changed so that local contribution need not exceed to percent of the total project cost and that public works which benefit any part of a project area including such public works that benefit the city as a whole be included as offisets to local costs."130 The adoption of such a proposal would eliminate virtually the entire local contribution to the program.

Finally, some of the pain now attached to the local share of the urban renewal costs may be psychological-and attributable to the relative newness of the program. That is, while the local burdens of the program are very real and may well become heavier as urban renewal activities are intensified, and while the critical fiscal problems faced by most of our cities are certainly onerous, it is nevertheless true that some of the resistance to local urban renewal expenditures results from the fact that cities have not yet become as accustomed to budgeting urban renewal expenditures as they are to budgeting police and fire and street and school expenditures.

\footnotetext{
1s: See statement by David M. Walker, Urban Renewal Commissioner, in Hearings Before the Subcomnittce on Housing of the Semute Committee on Banking and Currency on Housing Legislation of 1960 , 86h Congen 2 d Sess. 173, at 125 (1960).

196 Hearings Before the Suhcommitzee on Housing of the House Committec on Banking and Currency on Slum Clearance and Related Houssing Problems, 85th Cong., 2d Sess, 192 (1958).
} 
Yet the spokesmen for our cities are generally quick to defend the relative importance and desirability of the newer expenditures.

It is too much to expect that pressures and counterpressures with respect to sharing the costs of urban renewal will cease or that the issue will be resolved without leaving some undesirable distortions in the program. However, it is not too much to hope that the pendulum will not swing so far in either direction as to result in major harm to the program. 